\title{
Mesoporous silica nanoparticles for biomedical and catalytical applications
}

by

Xiaoxing Sun

\author{
A thesis submitted to the graduate faculty \\ in partial fulfillment of the requirements for the degree of \\ MASTER OF SCIENCE
}

Major: Chemistry

Program of Study Committee

Brian G. Trewyn, Co-major Professor

Ning Fang, Co-major Professor

Zhiqun Lin

Vivekananda Roy

Iowa State University
Ames, Iowa

2011

Copyright $($ C Xiaoxing Sun, 2011. All rights reserved. 


\section{TABLE OF CONTENTS}

ACKNOWLEDGEMENTS $\quad$ iii

ABSTRACT iv

CHAPTER $1 . \quad$ DISSERTATION ORGANIZATION 1

CHAPTER 2. CO-DELIVERY OF LUCIFERASE AND LUCIFERIN BY MESOPOROUS SILICA NANOPARTICLES FOR INTRACELLULAR CATALYSIS 2

$\begin{array}{ll}\text { Abstract } & 2\end{array}$

$\begin{array}{ll}\text { Article } & 3\end{array}$

$\begin{array}{ll}\text { Acknowledgement } & 14\end{array}$

$\begin{array}{ll}\text { References } & 15\end{array}$

$\begin{array}{ll}\text { Appendix: Supporting Information } & 17\end{array}$

CHAPTER 3 FUNCTIONALIZED MESOPOROUS SILICA NANOPARTICLE

BASED HETEROGENEOUS CATALYST FOR C-H BOND ACTIVATION

$\begin{array}{ll}\text { REACTION } & 27\end{array}$

$\begin{array}{ll}\text { 1. Introduction } & 27\end{array}$

2. Experimental methods 28

2.1. Synthesis of Bpy-amide-TES 28

2.2. Post-grafting method 29 
2.3. Co-condensation method

3. Results and discussion

4. Conclusion

References 


\section{ACKNOWLEDGEMENT}

I would like to convey my sincere thanks and deep appreciation to those who have supported and inspired me during these years.

First and foremost, I am deeply indebted to my major professor, Dr. Victor Shang-Yi Lin, whose enthusiasm, encouragement, creativity, patience and dedication to science. exemplified to me what a scientist should be. It is my supreme honor to be a graduate student in his research group. Although he is no longer with us, his words and deeds will continue to guide me in my future life.

My sincere gratitude also extends to my advisor Dr. Brian G. Trewyn, for his guidance for my research and his generous support with my degree completion.

My special thanks to my co-major professor Dr. Ning Fang, as well as my past and present Program of Study Committee Members, Dr. Zhiqun Lin, Dr. Vivekananda Roy, Dr. Nicola L. Pohl and Dr. Marek Pruski, for their time and insightful advices.

To my past and present group members, thank their patience and kindness with my research.

To my family whose encouragement has provided me enormous support during my life.

To all my friends, thank their care and friendship.

My best wishes to everyone whose entry into my life has supported and motivated me to pursue my dream. 


\begin{abstract}
Mesoporous silica materials, discovered in 1992 by the Mobile Oil Corporation, have received considerable attention in the chemical industry due to their superior textual properties such as high surface area, large pore volume, tunable pore diameter, and narrow pore size distribution. Among those materials, MCM-41, referred to Mobile Composition of Matter NO. 41, contains honeycomb liked porous structure that is the most common mesoporous molecular sieve studied. Applications of MCM-41 type mesoporous silica material in biomedical field as well as catalytical field have been developed and discussed in this thesis.
\end{abstract}

The unique features of mesoporous silica nanoparticles were utilized for the design of delivery system for multiple biomolecules as described in chapter 2 . We loaded luciferin into the hexagonal channels of MSN and capped the pore ends with gold nanoparticles to prevent premature release. Luciferase was adsorbed onto the outer surface of the MSN. Both the MSN and the gold nanoparticles were protected by poly-ethylene glycol to minimize nonspecific interaction of luciferase and keep it from denaturating. Controlled release of luciferin was triggered within the cells and the enzymatic reaction was detected by a luminometer. Further developments by varying enzyme/substrate pairs may provide opportunities to control cell behavior and manipulate intracellular reactions.

MSN was also served as a noble metal catalyst support due to its large surface area and its stability with active metals. We prepared MSN with pore diameter of $10 \mathrm{~nm}$ 
(LP10-MSN) which can facilitate mass transfer. And we successfully synthesized an organo silane, 2,2'-Bipyridine-amide-triethoxylsilane (Bpy-amide-TES). Then we were able to functionalize LP10-MSN with bipyridinyl group by both post-grafting method and co-condensation method. Future research of this material would be platinum complexation. This Pt (II) complex catalyst has been reported for a C-H bond activation reaction as an alternative of the traditional Friedel-Crafts reaction. And we will compare the turnover numbers of MSN supported material with homogenous catalyst to evaluate the catalytical efficiency of our material. 


\section{CHAPTER 1. DISSERTATION ORGANIZATION}

The dissertation is organized in four chapters. Chapter 1 describes the organization of this dissertation. Chapter 2 is a journal article and will be submitted for publication. Chapter 3 is a preliminary study of a collaborating project with researchers from University of Virginia. Chapter 4 concludes this dissertation and discusses future work of this research.

Chapter 2 presents a luciferase and luciferin co-delivery system for intracellular catalysis reactions. The aim of this chapter is to describe the design of this co-delivery system and demonstrate its in vitro application in triggering artificial intracellular reactions, converting biological energy into usable forms and controlling cell functions.

Chapter 3 discusses the synthesis of 2,2'-Bipyridine functionalized large pore mesoporous silica nanoparticle. This bipyridinyl group can further coupled with Pt which possesses potential use for $\mathrm{C}-\mathrm{H}$ bond activation reaction. The structure of the material and bipyridinyl group loading amount was investigated and reported in this chapter.

The last chapter is a brief conclusion of this dissertation with general achievements, potential applications and future goals. 


\title{
CHAPTER 2. CO-DELIVERY OF ENZYME AND SUBSTRATE USING MESOPOROUS SILICA NANOPARTICLES FOR INTRACELLULAR CONTROLLED CATALYTIC REACTION
}

\author{
Xiaoxing Sun, Yannan Zhao, Igor I. Slowing*, Brian G. Trewyn* and Victor S.-Y. Lin ${ }^{\dagger}$
}

Department of Chemistry, U.S. Department of Energy and Ames Laboratory, Iowa State University, Ames, Iowa 50011-3111, U.S.A.

Corresponding authors: e-mails: bgtrewyn@iastate.edu and islowing@iastate.edu; telephone: 515-294-8007, 515-294-6220; Fax: 515-294-4709

\begin{abstract}
A surface-modified gold nanoparticle end-capped mesoporous silica nanoparticle (MSN) was developed for intracellular co-delivery of enzyme (luciferaase) and substrate (luciferin) with retention of bioactivity. Intracellular controlled catalytic reaction was triggered by tuning intracellular reduing environment. The effectiveness of luciferase catalyzed luciferin reaction and luminescence emission in presence of $\mathrm{Mg}^{2+}$ and intracellular ATP was measured by luminometer. We envision that this MSN-based co-delivery system will provide a new approach for intracellular delivery of multiple bioactive molecules to reduce or enhance certain cellular activities, bring new cell functions, or convert biological energy (ATP) to usable forms.
\end{abstract}

KEYWORDS Mesoporous silica nanoparticle, co-delivery, luciferase, luciferin, ATP, intracellular catalysis 
The intracellular delivery and controlled release of biogenic molecules, such as genes, enzymes and proteins, and other molecules of pharmaceutical interest, ${ }^{1,2}$ provides a powerful tool for therapeutics and fundamental study of biological processes such as enzyme-catalyzed reactions. While significant progress in nanotechnology and drug delivery has led to the availability of intracellular delivery of membrane-impermeable enzymes, ${ }^{3-5}$ conducting biochemical or catalytic reactions inside living cells remains relatively unexplored. As a prelude to cellular applications, such as enzyme-catalyzed therapeutic activation (ECTA), ${ }^{6}$ it is desirable to develop a new biocompatible model system for intracellular delivery of multiple bioactive molecules to reduce or enhance certain cellular activities, bring new cell functions, or convert biological energy (ATP) to usable forms. There are two major challenges confronting the advancement of this field: the design of nanomaterials for intracellular controlled release of multiple biogenic species with preserved bioactivities and the development of methods for imaging and quantification of cellular catalytic reactions.

Recently, mesoporous silica nanoparticles (MSNs) have been demonstrated as an excellent candidate for co-delivery applications, ${ }^{7,8}$ owing to the co-existence of both interior pore and exterior particle surfaces for loading different guest molecules. This unique feature provides the possibility of using MSN for controlled release and co-delivery of enzyme and substrate for intracellular enzymatic reaction. Although many enzyme-catalyzed reactions could be targeted for this purpose, it is difficult to measure the dynamic effectiveness of such enzyme-substrate co-delivery systems. 
Enzymatic catalysis of light emission offers a unique tool for investigating the enzyme and substrate activities. ${ }^{9,10}$ Luciferase-mediated bioluminescence imaging has served as a reporting tool for monitoring various biological processes such as imaging reporter gene expression in living subjects. ${ }^{11}$ The luciferase-catalyzed oxidation of its substrate luciferin to oxyluciferin requires the presence of oxygen and $\mathrm{Mg}^{2+}$ ions, and is energetically enabled by the presence of ATP, which binds to the luciferase and thereby activates the enzyme. ${ }^{9,10}$ The bioluminescence emitted in this oxidation reaction is a direct measure of the effectiveness of this enzyme-catalyzed reaction. However, the use of luciferase has been limited to the additional injection of luciferin substrate.

Herein, we report on the synthesis and surface modification of a gold nanoparticle-capped MSN material for intracelluar co-delivery of enzyme luciferase and its substrate luciferin for intracellular controlled catalytic reaction. As depicted in Figure 1, luciferin is loaded in the mesopores of MSN and encapsulated with disulfide-linked gold nanoparticles that physically block luciferin from leaching out. Luciferase is physisorbed to the external surface of gold nanoparticle-capped MSN through electrostatic interactions. Luciferin molecules trapped inside the pores are released upon triggering by disulfide-reducing antioxidants, the presence of intracellular glutathione (GSH) or the introduction of dithiothreitol (DTT). The released luciferin would be converted by co-delivered luciferase to oxyluciferin and emission of photon, measurable with luminometer. 


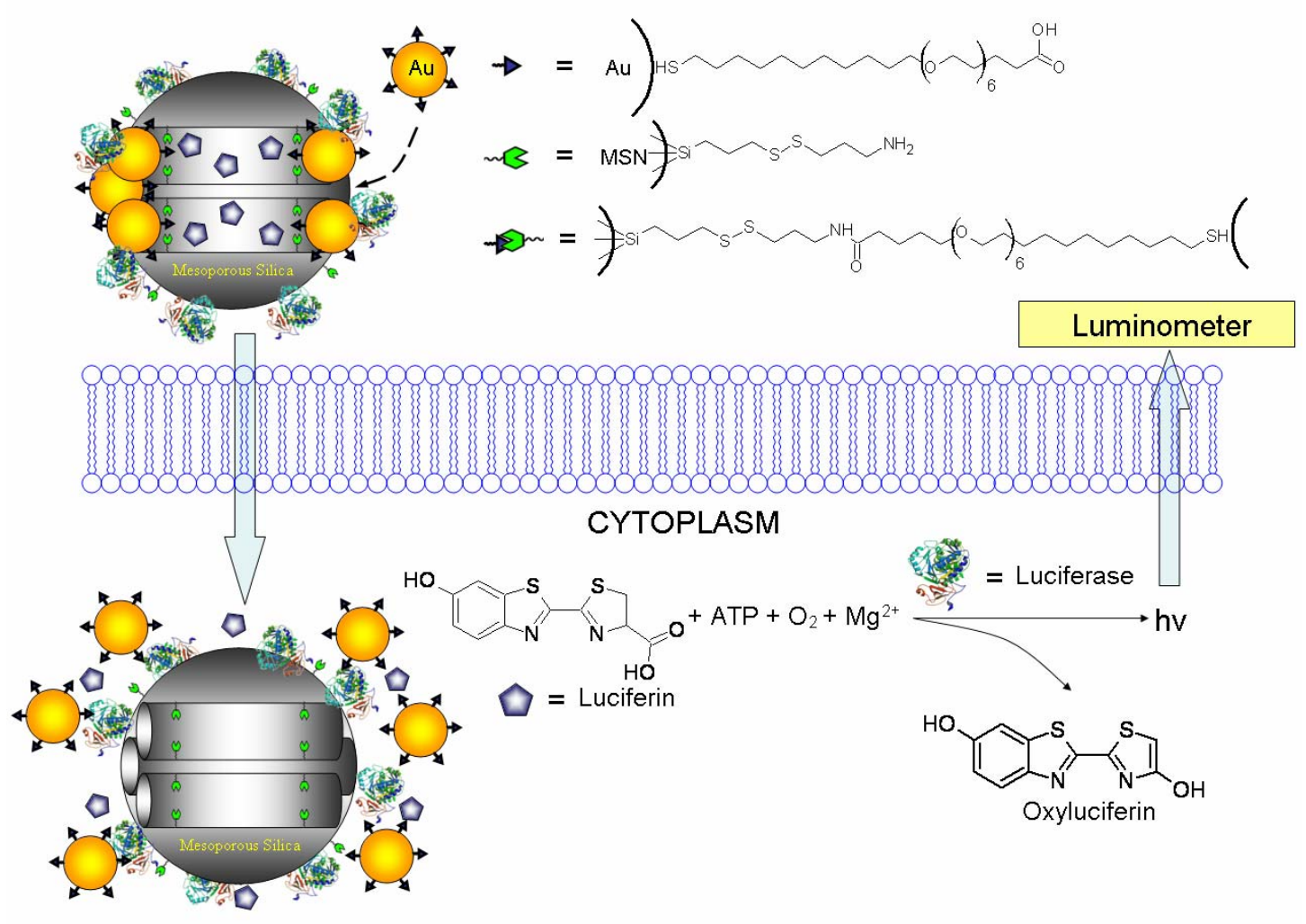

Figure 1. Schematic representation of mesoporous silica nanoparticles (MSNs) for intracellular controlled release of luciferase and luciferin.

We first synthesized a 2-(propyldisulfanyl)ethylamine $\left(0.9 \mathrm{mmol} \mathrm{g}^{-1}\right)$ functionalized mesoporous silica nanosphere (linker-MSN) material via a method that we previously reported. $^{12,13}$ As described in the Supporting Information (SI), the material was PEGlyated by grafting 2-[methoxy(polyethylenoxy)-propyl]trimethoxysilane to yield the PEGlyated $\left(0.1 \mathrm{mmol} \mathrm{g}^{-1}\right)$ linker-MSN with an average particle diameter of $160 \mathrm{~nm}$ and an MCM-41-type channel-like mesoporous structure $(\mathrm{BJH}$ pore diameter $=2.5 \mathrm{~nm})$ (Figure 2a). 

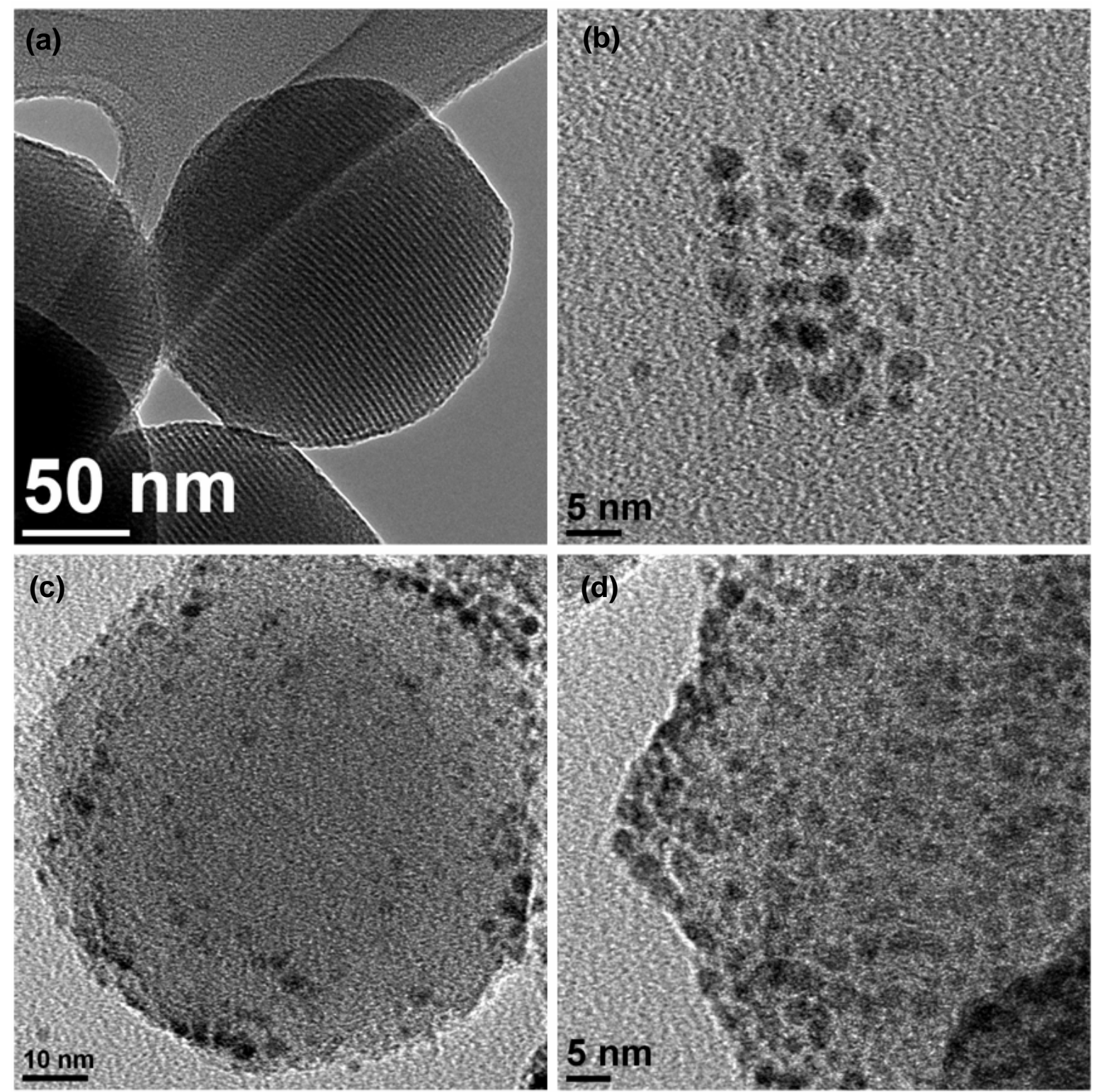

Figure 2. Transmission electron micrographs of (a) PEGlyated linker-MSN, (b) PEG-Au NPs, (c) and (d) luciferin-loaded Au-MSN.

We then functionalized the surface of the gold nanoparticle with a carboxylic acid-terminated polyethylene glycol (PEG) linker (shown in Figure 1) through ligand exchange reaction ${ }^{14}$ as detailed in the Supporting Information (SI). The organically

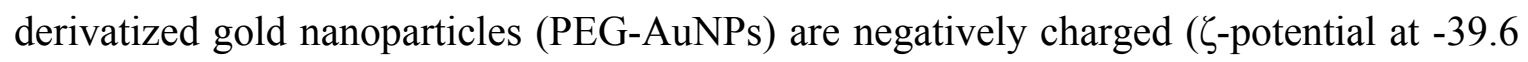


$\mathrm{mV}$ ) in PBS (pH 7.4) with an average particle diameter of $3 \mathrm{~nm}$ as determined by the transmission electron microscopy (Figure 2b).

Luciferase activity assays as described in the SI demonstrated that the particle surface properties of both MSN and gold nanoparticle play a crucial role in the retention of enzyme bioactivity, which is consistent with other literature reports. ${ }^{15}$ With MSN and gold nanoparticle surface PEGlyation, $75 \%$ and $63 \%$ of luciferase activity of was preserved after $2 \mathrm{~h}$ incubation at $37{ }^{\circ} \mathrm{C}$, respectively. In contrast, linker-MSN and 1-propanethiol-stabilized gold nanoparticles inhibited over $80 \%$ of luciferase activity.

The mesopores of PEGlyated linker-MSN (25 mg) were loaded with luciferin $(33 \mu \mathrm{M})$ in PBS buffer (pH 7.4) and then capped with PEG-Au NPs (25 mg) through amide bond formation between the carboxylic acid groups of PEG-Au NP and amino groups of PEGlyated linker-MSN (Figure 1), giving rise to the desired luciferin-loaded Au-MSN (Figure 2c and d). The loading of luciferin were determined to be $13.1 \mu \mathrm{mol} \mathrm{g}^{-1}$ by fluorescence emission spectroscopy.

TEM microscopy was used to confirm the capping of PEG-Au NPs to the pore entrances of PEGlyated linker-MSN. Figure 2 shows the TEM micrographs of PEGlyated linker-MSN before and after capping with PEG-AuNPs. In the case of the uncapped MSN (Figure 2a), the hexagonally packed mesoporous channels could be clearly visualized. In contrast, the TEM micrographs of gold nanoparticle-capped MSN (Figure 2c and d) show dark spots on MSN surface, representing the attachment of gold nanoparticles on the exterior surface of MSN. 
To determine if release of luciferin from the conjugates could be induced by disulfide cleavage as desired for intracellular release, luciferin loaded Au-MSN (1 mg mL $\left.{ }^{-1}\right)$ was suspended in PBS buffer (pH 7.4) for $23 \mathrm{~h}$ before addition of $1 \mathrm{mM}$ DTT. As shown in Figure 3a, the Au-MSN drug delivery system exhibited less than $5.0 \%$ of drug release in PBS buffer over a period of $23 \mathrm{~h}$. The result suggested a good capping efficiency of the gold nanoparticles for encapsulation of the luciferin molecules against leaching. Addition of disulfide-reducing molecules, DTT $(1 \mathrm{mM})$ triggered a rapid release of the mesopore-entrapped luciferin. Within $10 \mathrm{~h}$, the release reached $100 \%$ of the total release corresponding to ca. $11 \%$ of the total luciferin loading. 


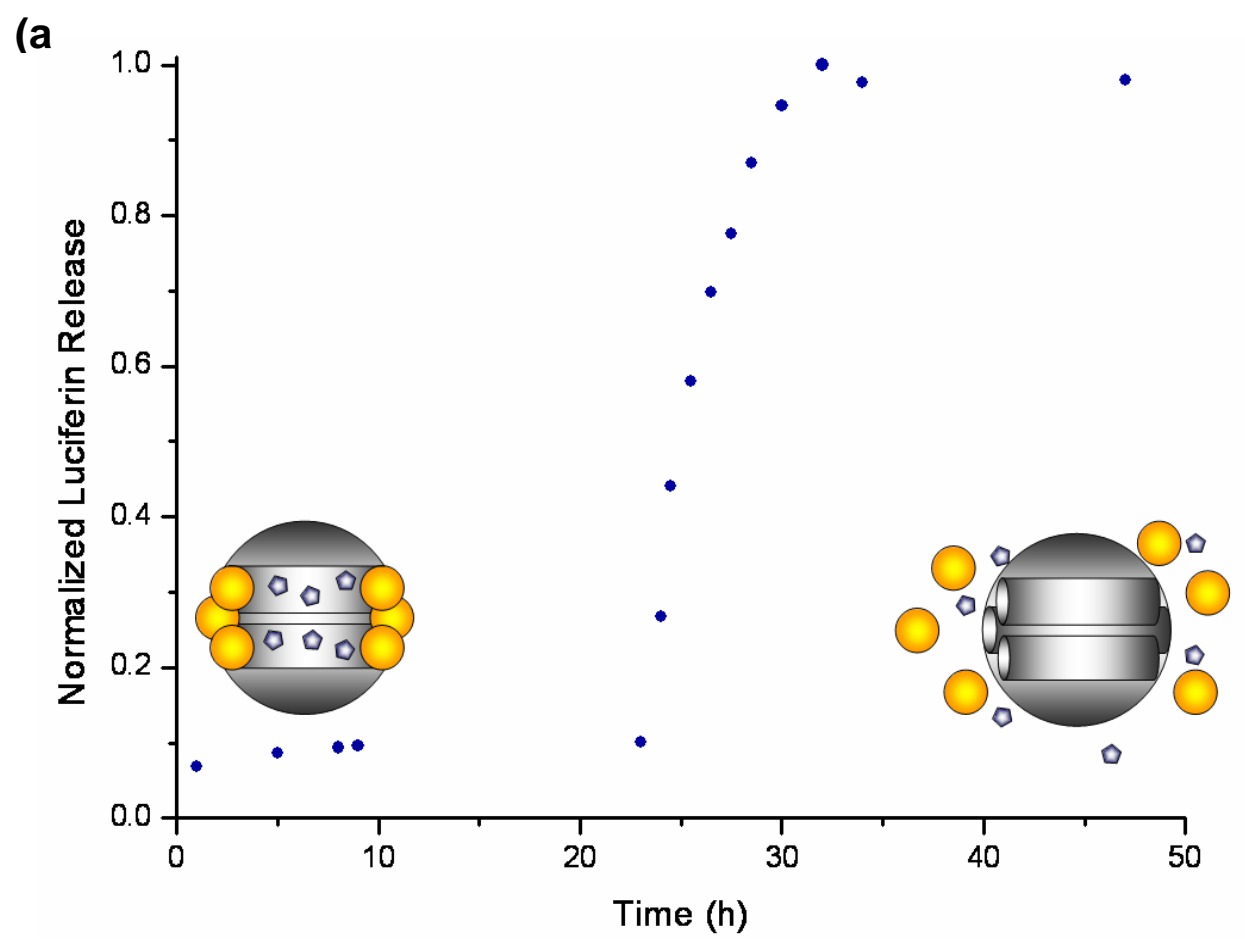

(b)

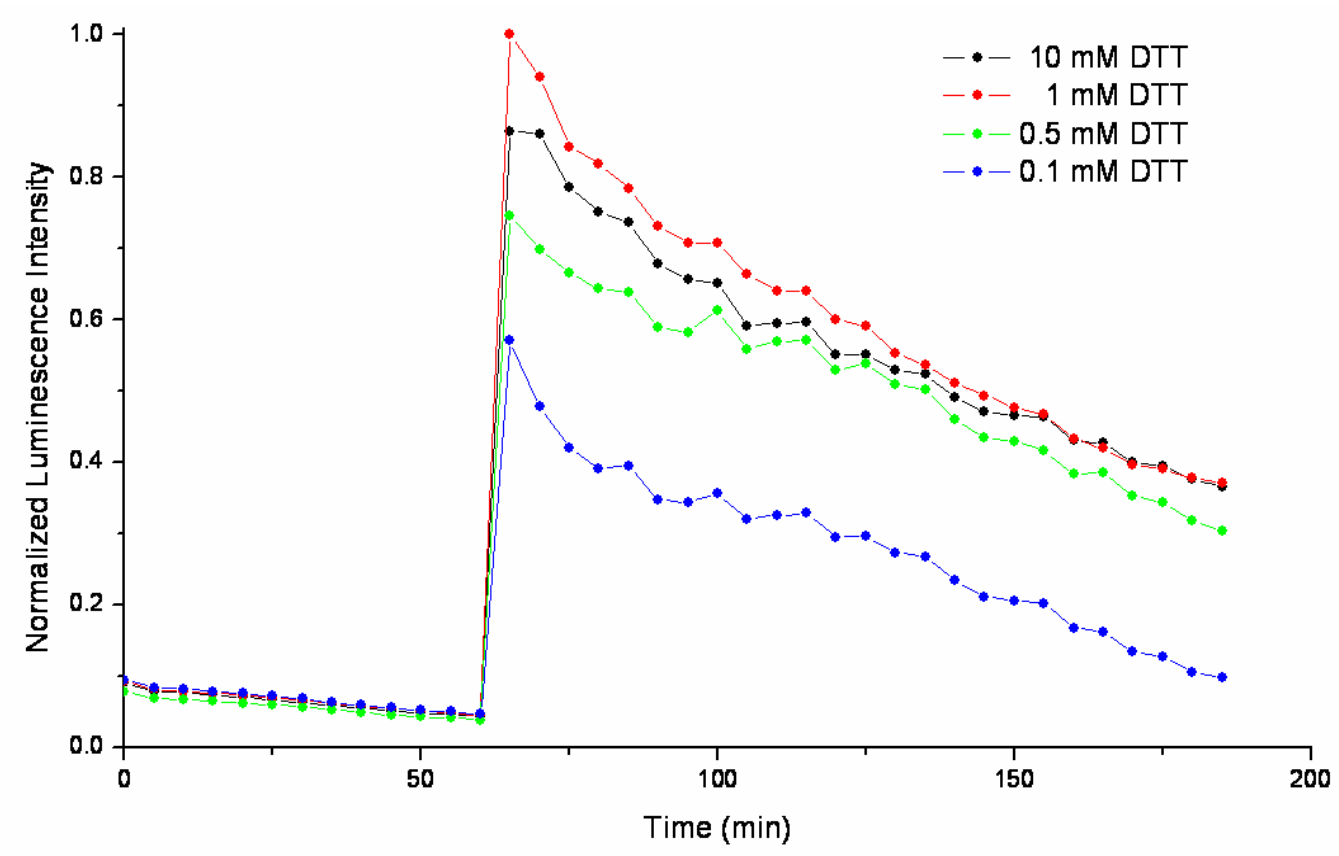

Figure 3. (a) Controlled release of luciferin from luciferin-loaded Au-MSN (1 mg mL $\left.{ }^{-1}\right)$ triggered by $1 \mathrm{mM}$ dithiothreitol (DTT) at $\mathrm{pH} 7.4$; (b) Observed bioluminescence from luciferase-luciferin Au-MSN (1 mg mL $\left.{ }^{-1}\right)$ as a function of time after addition of 0.1, 0.5 and $1 \mathrm{mM}$ DTT at $\mathrm{pH} 7.4$. 
The most advantageous feature of the MSN technology is its potential to deliver different biogenic species simultaneously in a controlled fashion. To construct the enzyme-substrate co-delivery system, the luciferin-loaded Au-MSN (1 mg mL $\left.{ }^{-1}\right)$ was mixed with luciferase $\left(1 \mathrm{mg} \mathrm{mL} \mathrm{mL}^{-1}\right)$ in PBS buffer ( $\left.\mathrm{pH} 7.4\right)$ for $2 \mathrm{~h}$, followed by centrifugation and freeze drying to generate the luciferase adsorbed and luciferin loaded Au-MSN (luciferase-luciferin Au-MSN). To examine the applicability of this co-delivery system, luciferase activity assays were carried out in a 96-well plate using a standard procedure, as described in the SI. The luminescence intensity remained at background level over a period of 60 minutes before the addition of disulfide bond reducing agents, suggesting a "zero premature release" property of this system. After addition of DTT $(1 \mathrm{mM})$, luciferin was released and converted to oxyluciferin catalyzed by luciferase pre-adsorbed on the external surface of Au-MSN. As shown in Figure 3b, the pattern of luminescence as a function of time was similar for all DTT doses $(0.1,0.5$, 1 and $10 \mathrm{mM}$ ). The highest luminescence signal was detected in 5 minutes and gradually decayed, reaching background after approximately $180 \mathrm{~min}$. The observed luminescence strongly depends on the concentration of DTT. An increase in the luminescence signal was observed with increasing DTT dose up to $1 \mathrm{mM}$, suggesting a dose-dependent controlled release profile. Interestingly, when $10 \mathrm{mM}$ DTT was introduced to the system, the luminescence showed a $15 \%$ decrease in intensity compared to the signal triggered by $1 \mathrm{mM}$ DTT, which can be attributed to the denaturation of luciferase by high DTT concentrations. 
To demonstrate that the enzyme-substrate Au-MSN system can simultaneously delivery both the enzyme luciferase and the substrate luciferin for intracellular enzyme-catalyzed reaction, luciferase-luciferin Au-MSN (50 $\mu \mathrm{g} \mathrm{mL} \mathrm{m}^{-1}$ ) was allowed to be internalized by human cervical carcinoma (Hela) cells. After $3 \mathrm{~h}$ incubation, the intracellular luciferase-catalyzed luciferin conversion and light emission was initiated by the addition of $2 \mu \mathrm{mol} \mathrm{Mg}^{2+}$. As shown in Figure 4a, luminescence was generated immediately after the injection of $\mathrm{Mg}^{2+}$ and slowly decayed over the next $30 \mathrm{~min}$, whereas almost no signal was detected when free solutions of luciferase and luciferin were injected, suggesting the capability of this MSN system for co-delivery of enzyme and substrate and controlled release of loaded-substrate triggered by intracellular reducing environment. Upon addition of $1 \mathrm{mM}$ DTT following the decay of the intracellular redox-potential triggered luminescence, a significant signal is generated within $10 \mathrm{~min}$, followed by a gradual decay, consistent with the observation from the ex vivo experiment (Figure 3b).

To confirm the observed luminescence was due to intracellular release of luciferin and its reaction with co-delivered luciferase but not the presence of extracellular ATP arising from the material-induced apoptosis, the cell viability was evaluated by Guava ViaCount cytometry assay after $24 \mathrm{~h}$ incubation with luciferase-luciferin Au-MSN at different concentrations $\left(20,50,100 \mu \mathrm{g} \mathrm{ml}^{-1}\right)$. Over $95 \%$ of viable cells were observed when up to $100 \mu \mathrm{g} \mathrm{ml}^{-1}$ of the material was incubated with Hela cells (Figure S6). 
(a)

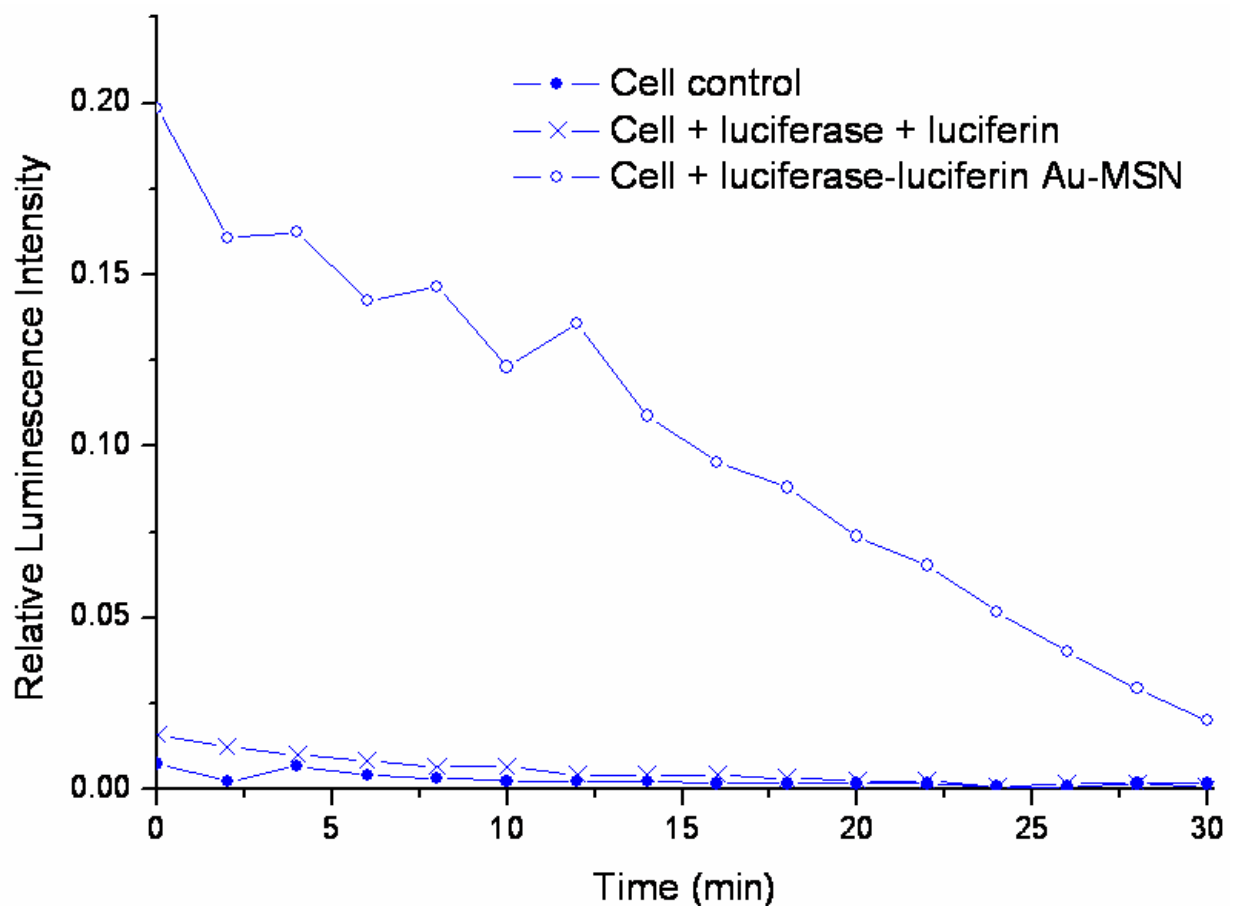

(b)

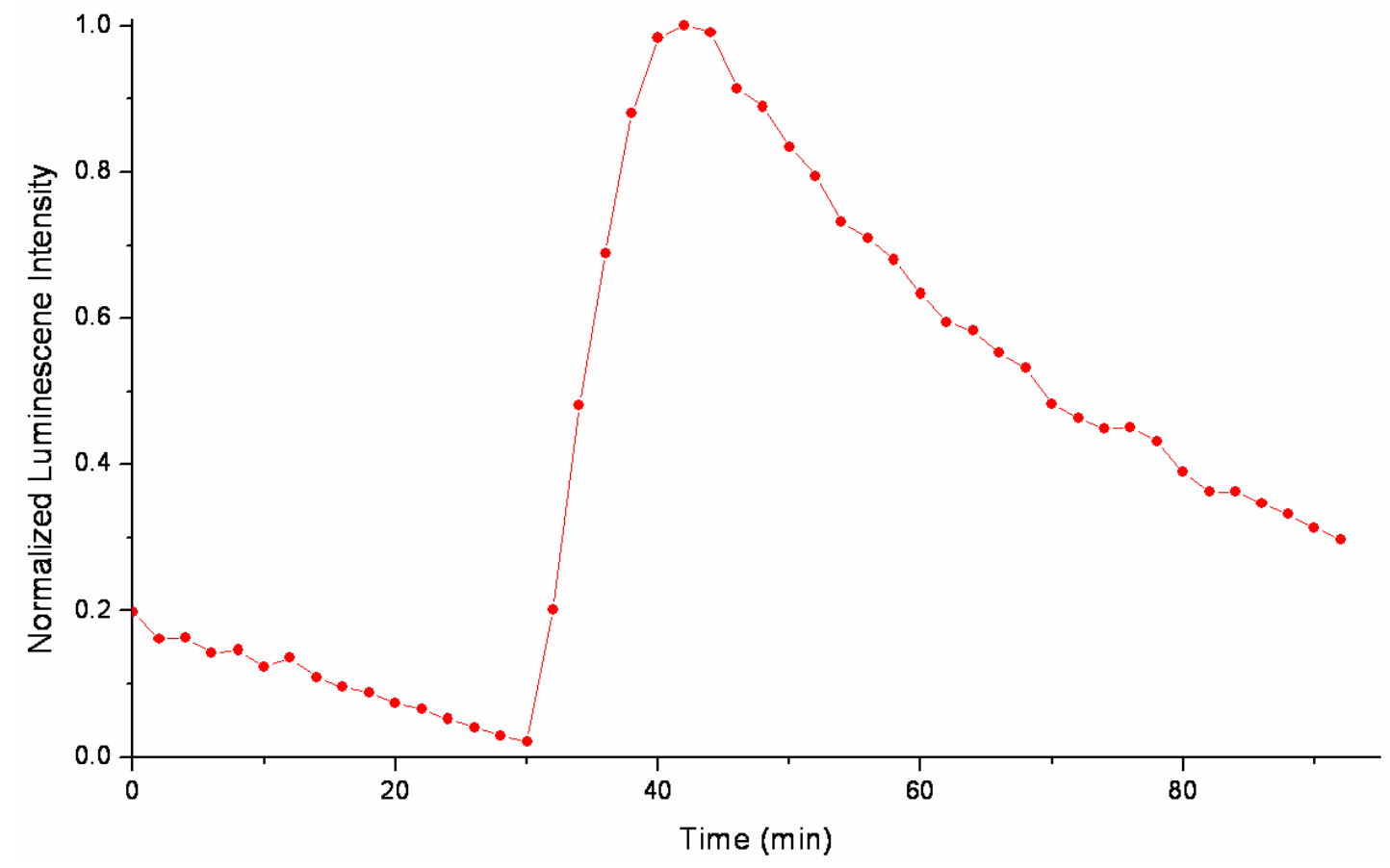

Figure 4. (a) in vitro bioluminescence intensity of Hela cells (dot), Hela cells incubated with free luciferase and luciferin (cross) and Hela cells incubated with luciferase-luciferin Au-MSN (circle). (b) Controlled intracellular catalytic reaction from Hela cells 
incubated with luciferase-luciferin Au-MSN $\left(50 \mu \mathrm{g} \mathrm{mL}^{-1}\right)$ triggered by $1 \mathrm{mM}$ dithiothreitol (DTT) at $\mathrm{pH} 7.4$.
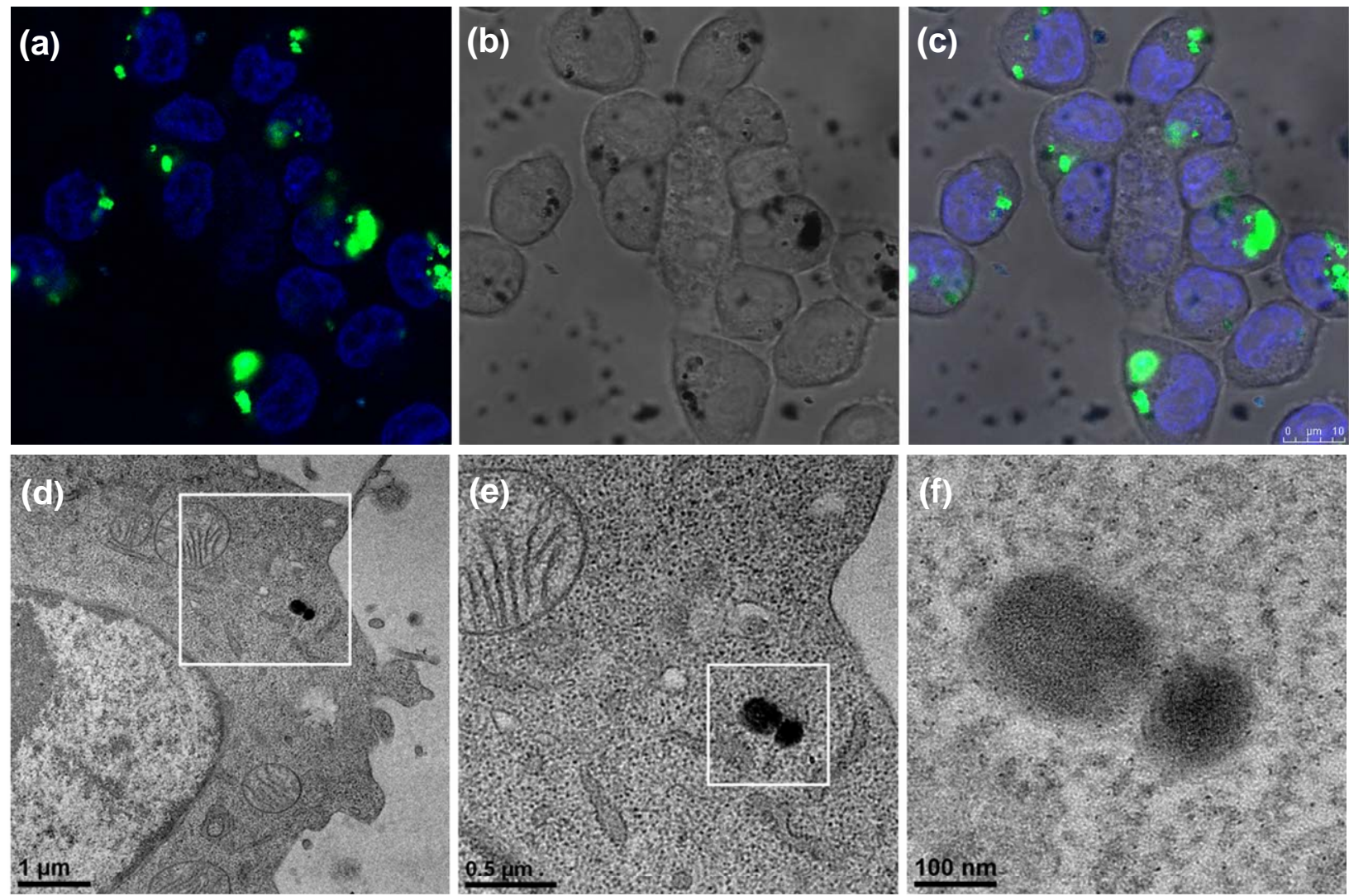

Figure 5. (a) Fluorescence confocal micrographs of Hela cells internalized with $50 \mu \mathrm{g}$ $\mathrm{mL}^{-1}$ of luciferase-luciferin FITC-Au-MSN (green) for $3 \mathrm{~h}$. Cell nuclei were stained with DAPI(blue). (b) Corresponding bright field image of Hela cells. (c) Fluorescence confocal and bright field merged image. (d-f) Transmission electron micrographs of Hela cells internalized with $50 \mu \mathrm{g} \mathrm{mL}^{-1}$ of luciferase-luciferin FITC-Au-MSN for $3 \mathrm{~h}$. Images increase in magnification from left to right.

The cellular uptake properties were examined and visualized by confocal fluorescence microscopy and transmission electron microscopy (TEM). MSNs were labeled with 
FITC as described in SI to yield fluorescence emission at $520 \mathrm{~nm}$. Luciferase-luciferin FITC-Au-MSN (50 $\left.\mu \mathrm{g} \mathrm{mL} \mathrm{m}^{-1}\right)$ was incubated with Hela cells for $3 \mathrm{~h}$ and was indeed internalized by Hela cells as depicted by fluorescence confocal micrographs (Figure 5a-c). TEM samples were prepared as described in SI. TEM images (Figure 5d-f) also confirmed the successful endocytosis of luciferase-luciferin Au-MSN.

The synthesis and performance of this enzyme-substrate Au-MSN co-delivery system establishes an operational facile method for intracellular controlled catalytic reaction. The effectiveness of the enzyme-catalyzed reaction inside living cells can be tuned by varying the intracellular reducing environment. The luciferase-luciferin Au-MSN system was designed to allow imaging and quantification of the intracellular catalysis, thereby providing a practical method to evaluate the effectiveness of intracellular enzyme and substrate co-delivery. In addition, it has been recently observed that MSNs are able to undergo exocytosis and harvest intracellular molecules. ${ }^{16}$ These findings suggest that MSN could serve not only as vehicles for co-delivering enzyme and substrate into living cells but also for sequestering the product out of cells for a variety of biotechnological applications.

Acknowledgment. This work is dedicated to the memory of our dear colleague Dr. Victor Shang-Yi Lin. This research was supported by the U.S. National Science Foundation (CHE-0809521). 
Supporting Information Available. Experimental procedures, materials characterization and additional figures. This material is available free of charge via the internet at http://pubs.acs.org.

\section{REFERENCES}

1. Zhao, Y.; Vivero-Escoto, J. L.; Slowing, I. I.; Trewyn, B. G.; Lin, V. S. Y. Expert Opin. Drug Delivery 2010, 7, (9), 1013-1029.

2. Vivero-Escoto, J. L.; Slowing, I. I.; Trewyn, B. G.; Lin, V. S. Y. Small 2010, 6, (18), 1952-1967.

3. Slowing, I. I.; Trewyn, B. G.; Lin, V. S. Y. J. Am. Chem. Soc. 2007, 129, (28), 8845-8849.

4. Ghosh, P.; Yang, X.; Arvizo, R.; Zhu, Z.-J.; Agasti, S. S.; Mo, Z.; Rotello, V. M. J. Am. Chem. Soc. 2010, 132, (8), 2642-2645.

5. Bale, S. S.; Kwon, S. J.; Shah, D. A.; Banerjee, A.; Dordick, J. S.; Kane, R. S. ACS Nano 2010, 4, (3), 1493-1500.

6. Lackey, D. B.; Groziak, M. P.; Sergeeva, M.; Beryt, M.; Boyer, C.; Stroud, R. M.; Sayre, P.; Park, J. W.; Johnston, P.; Slamon, D.; Shepard, H. M.; Pegram, M. Biochem. Pharmacol. 2001, 61, (2), 179-189.

7. Zhao, Y.; Trewyn, B. G.; Slowing, I. I.; Lin, V. S. Y. J. Am. Chem. Soc. 2009, 131, (24), 8398-8400.

8. Torney, F.; Trewyn, B. G.; Lin, V. S. Y.; Wang, K. Nat. Nanotechnol. 2007, 2, (5), 295-300. 
9. DeLuca, M.; McElroy, W. D. Biochemistry 1974, 13, (5), 921-5.

10. Lundin, A.; Rickardsson, A.; Thore, A. Anal. Biochem. 1976, 75, (2), 611-20.

11. Bhaumik, S.; Gambhir, S. S. Proc. Natl. Acad. Sci. U. S. A. 2002, 99, (1), 377-382.

12. Lai, C.-Y.; Trewyn, B. G.; Jeftinija, D. M.; Jeftinija, K.; Xu, S.; Jeftinija, S.; Lin, V.

S. Y. J. Am. Chem. Soc. 2003, 125, (15), 4451-4459.

13. Giri, S.; Trewyn, B. G.; Stellmaker, M. P.; Lin, V. S. Y. Angew. Chem., Int. Ed. 2005, 44, (32), 5038-5044.

14. Cutler, E. C.; Lundin, E.; Garabato, B. D.; Choi, D.; Shon, Y.-S. Mater. Res. Bull. 2007, 42, (6), 1178-1185.

15. Hong, R.; Fischer, N. O.; Verma, A.; Goodman, C. M.; Emrick, T.; Rotello, V. M. J. Am. Chem. Soc. 2004, 126, (3), 739-743.

16. Slowing, I. I.; Vivero-Escoto, J. L.; Zhao, Y.; Kandel, K.; Peeraphatdit, C.; Trewyn, B. G.; Lin, V. S. Y. Small Accepted. 


\section{Appendix: Supporting Information}

Synthesis of 1-propanethiol stabilized gold nanoparticles. Following a reported procedure ${ }^{1}, \mathrm{HAuCl}_{4}(354.4 \mathrm{mg})$ was dissolved in $\mathrm{H}_{2} \mathrm{O}(30 \mathrm{ml})$, mixed with a solution containing $\mathrm{N}\left(\mathrm{C}_{8} \mathrm{H}_{17}\right)_{4} \mathrm{Br}(2.187 \mathrm{~g})$ and toluene $(80 \mathrm{ml})$. The two phase mixture was vigorously stirred for $20 \mathrm{~min}$ and the organic phase was collected, followed by the addition of 1-propanethiol $(68.5 \mathrm{mg})$ and $\mathrm{NaBH}_{4}$ solution. The solution was stirred at room temperature for 3 hours and the organic phase was separated. The solvent was removed under reduced pressure and the remaining product was mixed with $400 \mathrm{ml}$ ethanol. The mixture was kept at $-18^{\circ} \mathrm{C}$ until dark brown solid precipitated. Finally, the dark brown solid was centrifuged and washed with ethanol several time to afford 1-propanethiol stabilized gold nanoparticles.

Synthesis of 2-(2-\{2-[2-(2-[2-(11-mercapto-undecyloxy)-ethoxy]-ethoxy)-ethoxy] -ethoxy\}-ethoxy)-ethoxy-acetic acid (Thiolalkyl-EG6-COOH) stabilized gold nanoparticles. 1-propanethiol stabilized gold nanoparticles $(20 \mathrm{mg})$ were dissolved in $20 \mathrm{ml}$ dichloromethane. Thiolalkyl-EG6-COOH (474 $\mathrm{mg})$ was dissolved in dichloromethane and added into the gold nanoparticles solution. The mixture was stirred at room temperature for 24 hours. The solid was centrifuged, washed with dichloromethane and dried under high vacuum.

\section{Synthesis of thiol group functionalized mesoporous silica nanoparticle}

(thiol-MSN). $\quad N$-Cetyltrimethylammonium bromide (CTAB; $1.00 \mathrm{~g}$ ) was dissolved in $480 \mathrm{~mL}$ of nanopure water. $\mathrm{NaOH}(\mathrm{aq})(2.00 \mathrm{M}, 3.50 \mathrm{~mL})$ was introduced to the 
CTAB solution at $353 \mathrm{~K}$. Tetraethoxysilane (TEOS, $5.00 \mathrm{~mL}, 22.4 \mathrm{mmol}$ ) and 3-mercaptopropyltrimethylsilane (MPTMS, 1.00ml, $5.4 \mathrm{mmol}$ ) was dropwisely added to the CTAB solution under vigorous stirring. The mixture was allowed to react for $2 \mathrm{~h}$ to genrate a white precipitate. This solid crude product was filtered, washed with nanopure water and methanol, and dried under high vacuum to yield the as-synthesized thiol-MSN.

Synthesis of PEG functionalized thiol-MSN. As-synthesized thiol-MSN (1.00 g) was suspended in anhydrous toluene $(80 \mathrm{ml})$, followed by the addition of 2-[methoxy(polyethylenoxy)-propyl]trimethoxysilane (PEG-silane; $1 \mathrm{mmol}$ ). The dispersion was refluxed for 20 hours. The solid was filtered, washed with toluene and methanol and dried under high vacuum. The surfactant was removed by refluxing the material $(1.00 \mathrm{~g})$ in $1.0 \mathrm{ml}$ of $\mathrm{HCl}(37.4 \%)$ and $100 \mathrm{ml}$ of methanol for 6 hours. After that, the material was washed extensively with methanol and placed under high vaccum to remove remaining solvent.

\section{Synthesis of PEG functionalized 3-(Propyldisulfanyl)propylamine-MSN}

(PEGlyated linker-MSN). Surfactant-free PEG functionalized thiol-MSN (0.20 g) and 2-aldrithiol $(0.75 \mathrm{~g})$ was dissolved in ethanol $(80 \mathrm{ml})$. The mixture was stirred at room temperature for 24 hours to undergo the disulfide bond exchange reaction. The solid was collected, washed with ethanol and dried under high vacuum. The white powder was resuspended in $30 \mathrm{ml}$ ethanol, followed by the dropwise addition of aminoethanethiol $(0.18 \mathrm{~g})$ in $20 \mathrm{ml}$ ethanol solution. The dispersion was stirred at room temperature for 
24 hours. PEGlyated-linker-MSN was centrifuged, washed with copious ethanol and dried under high vacuum.

Characterization. XRD patterns of the MSN materials were collected in a Rigaku ultima IV X-ray diffractometer using $\mathrm{Cu} \mathrm{K} \alpha$ irradiation. $\mathrm{N}_{2}$ adsorption/desorption analysis was measured by nitrogen sorption isotherms in a Micromeritics Tristar 3000 sorptometer. The surface areas were calculated by the Brunauer-Emmett-Teller (BET) method, and the pore size distribution was calculated by the Barrett-Joyner-Halenda (BJH) method.

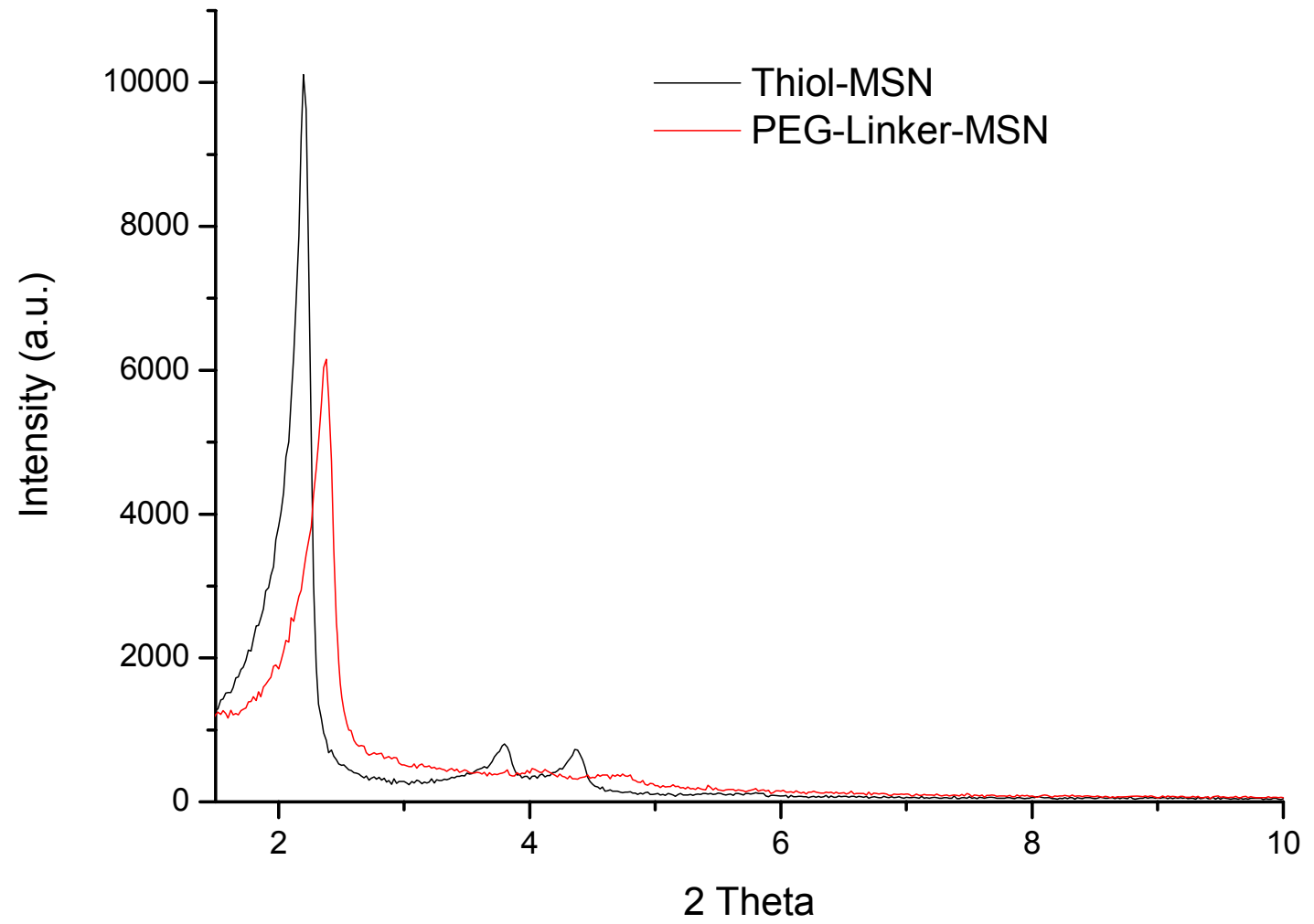

Figure S1: Low angle X-ray diffraction pattern of Thiol-MSN (black) and PEG functionalized linker-MSN (red) 


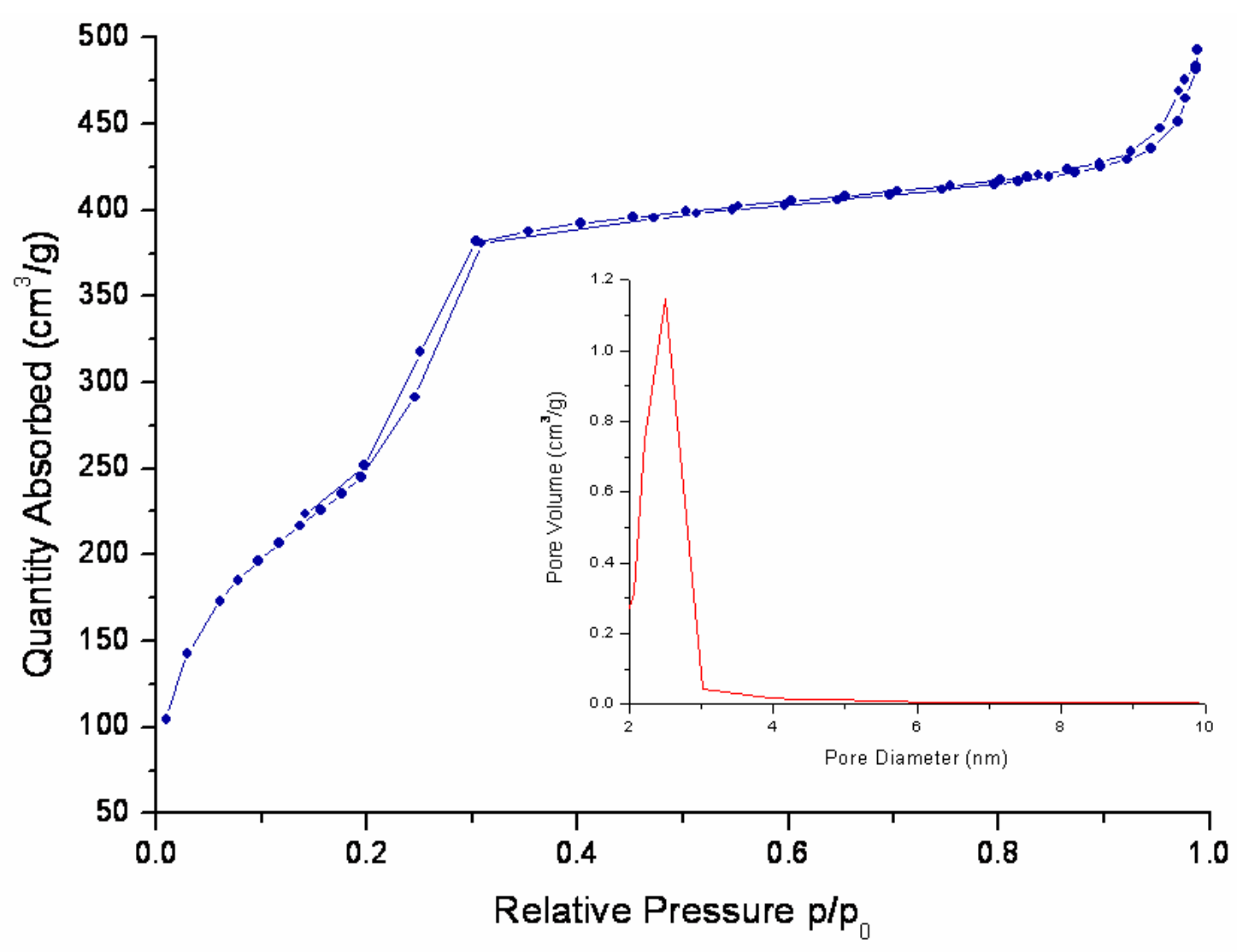

Figure S2: $\mathrm{N}_{2}$ adsorption/desorption isotherms and pore size distribution of PEGlyated linker-MSN

Table S1: BET and BJH parameters

\begin{tabular}{|c|c|c|c|}
\hline Material & $\begin{array}{c}\text { BET surface area } \\
\mathrm{S}_{\mathrm{BET}}\left(\mathrm{m}^{2} / \mathrm{g}\right)\end{array}$ & $\begin{array}{c}\text { BET Pore Volume } \\
V_{\mathrm{P}}\left(\mathrm{cm}^{3} / \mathrm{g}\right)\end{array}$ & $\begin{array}{c}\text { BJH Pore diameter } \\
\mathrm{W}_{\mathrm{BJH}}(\AA)\end{array}$ \\
\hline PEGlyated linker-MSN & 929 & 0.698 & 25.0 \\
\hline
\end{tabular}

Loading experiment. Linker-MSN (25.0 mg) was added to $10 \mathrm{ml}$ D-luciferin solution (PBS solution; $\mathrm{pH} 7.4 ; 35.7 \mu \mathrm{M}$ ) and the mixture was stirred at room temperature for 24 hours. Thiolalkyl-EG6-COOH stabilized gold nanoparticles $(25.0 \mathrm{mg})$ were suspended in the same solution along with the addition of N-hydroxysuccinimide (NHS; 
$10 \mathrm{mg}$ ) and 1-ethyl-3-(3-dimethylaminopropyl) carbodiimide hydrochloride (EDC; 10 mg). The mixture was stirred for another 24 hours before the precipitate was filtered, washed several times $(>8)$ with PBS solution and dried under vacuum. The washing solution was also collected and measured with fluorescence microscopy (FluoroMax-2, $\lambda_{\text {ex }}: 330 \mathrm{~nm}, \lambda_{\text {em }}: 535 \mathrm{~nm}$ ). Loading of luciferin was quantified by the concentration difference between original solution and washing solution.

Releasing experiment. Luciferin-loaded Au-MSN material (5 mg) was suspended in $5 \mathrm{ml}$ PBS solution. The suspension was stirred at room temperature for 23 hours and the amount of luciferin that leaked from the material was quantified by fluorescence microscopy (FluoroMax-2, $\lambda_{\text {ex }}: 330 \mathrm{~nm}, \lambda_{\text {em }}: 535 \mathrm{~nm}$ ). Then, dithiothreitol (DTT) was added and made a final concentration of DTT to be $1 \mathrm{mM}$. The mixture was stirred for another 23 hours. Release of luciferin was monitored at different time intervals with fluorescence microscopy.

Loading of luciferase onto MSN. Luciferin-loaded Au-MSN material (1 mg) was added into $1 \mathrm{ml}$ luciferase solution ( $\mathrm{pH} 7.4 \mathrm{PBS} ; 1 \mathrm{mg} / \mathrm{ml}$ ). This mixture was let in contact for 2 hours. Then, luciferase physisorbed MSN was washed three times with PBS solution and freeze dried.

Luciferase activity assay. Luciferase acitivty was measured by the bioluminescence intensity generated from luciferin-ATP reaction. In our study, $2 \mu$ mol of $\mathrm{MgSO}_{4}, 0.02 \mu \mathrm{mol}$ of ATP and $0.01 \mu \mathrm{mol}$ of luciferin were mixed. Pure enzyme or luciferase-physisorbed MSN was added to the mixture at different concentrations. PBS 
solution was added to make the final volume to be $250 \mu \mathrm{L}$. Luminescence intensity was measured by a luminometer of a microplate reader (Synergy MX).

(a)

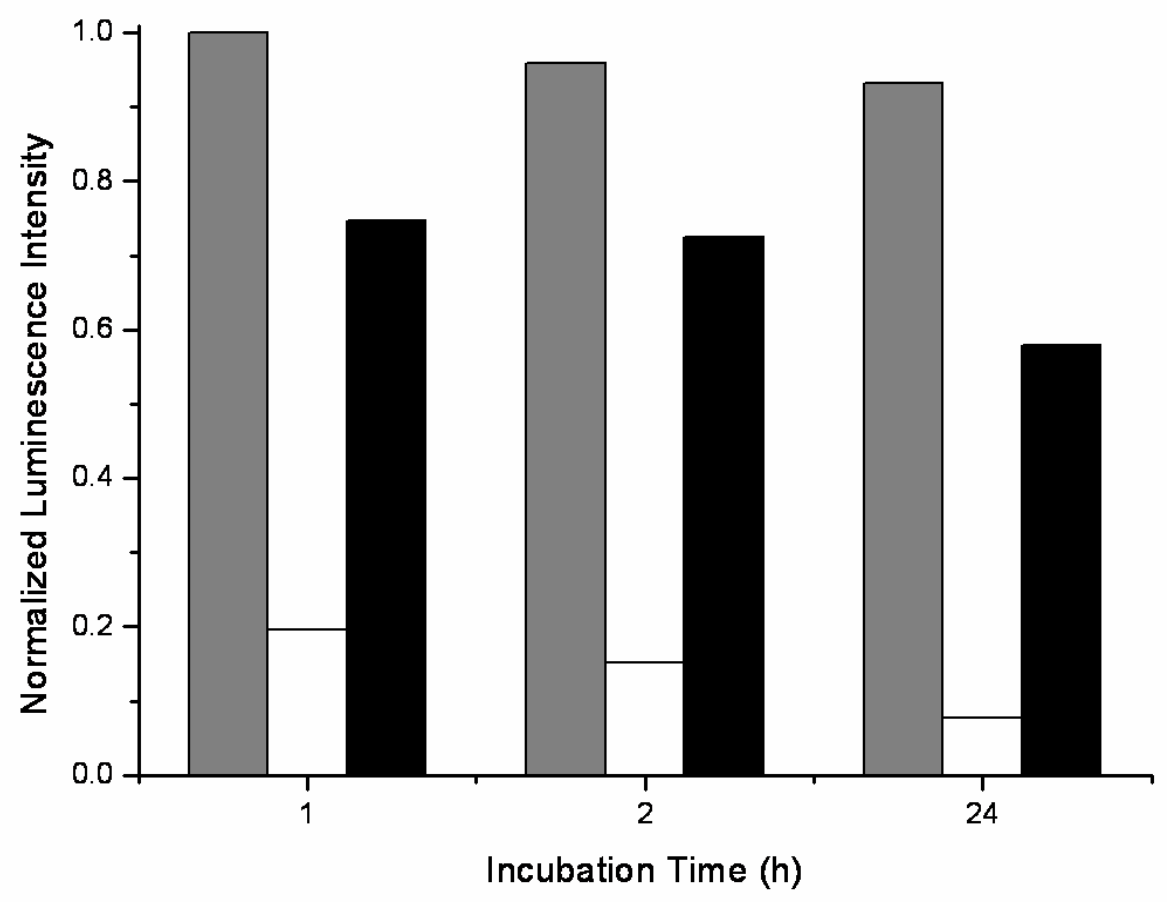

(b)

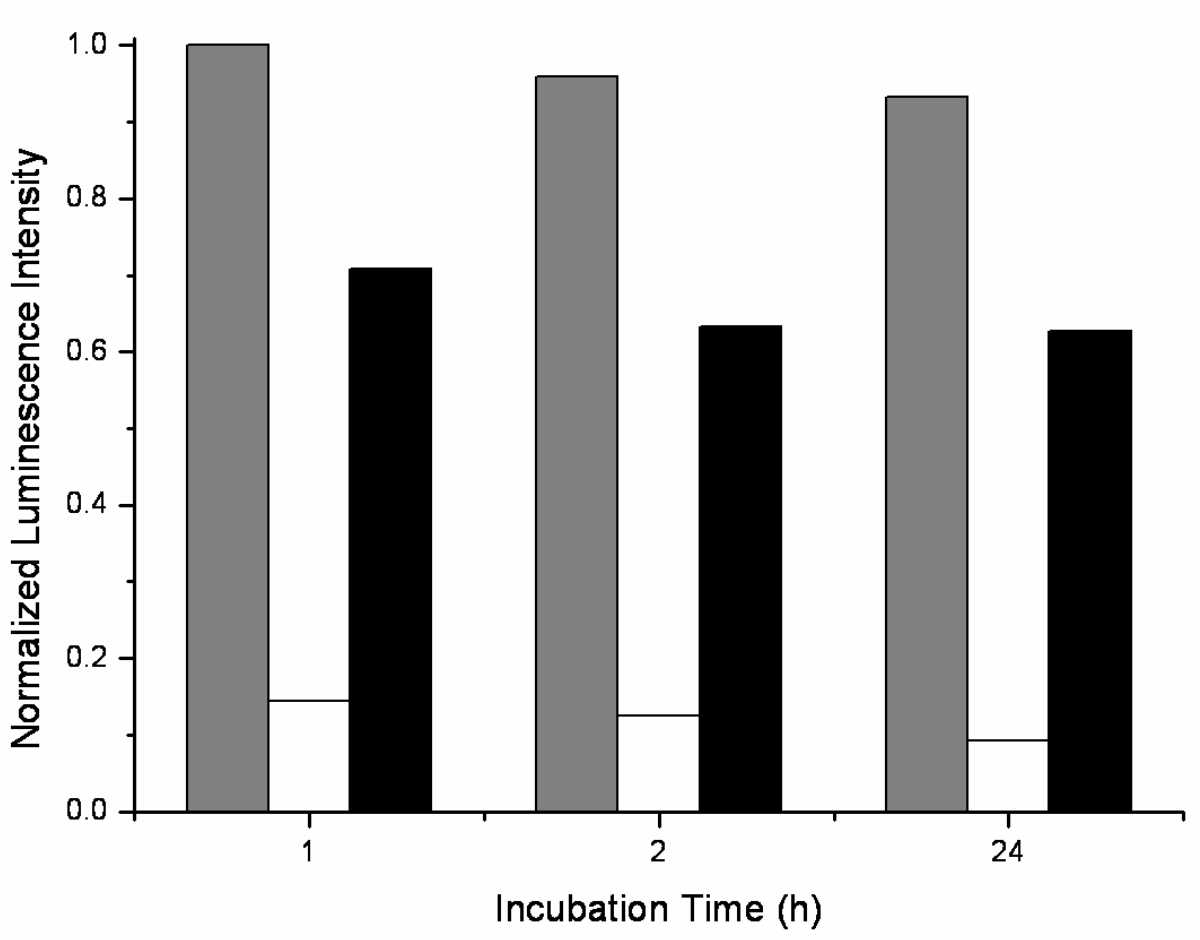

Figure S3: (a) Observed bioluminescence intensity from luciferase activity assay using pure luciferase $\left(1 \mathrm{mg} \mathrm{mL}^{-1}\right)$ (gray), luciferase $\left(1 \mathrm{mg} \mathrm{mL}^{-1}\right)$ incubated with linker-MSN 
$\left(0.5 \mathrm{mg} \mathrm{mL}^{-1}\right)$ (white) and luciferase $\left(1 \mathrm{mg} \mathrm{mL}^{-1}\right)$ incubated with PEGlyated linker-MSN $\left(0.5 \mathrm{mg} \mathrm{mL}^{-1}\right)$ (black). (b) Observed bioluminescence intensity from luciferase activity assay using pure luciferase $\left(1 \mathrm{mg} \mathrm{mL}^{-1}\right)$ (gray), luciferase $\left(1 \mathrm{mg} \mathrm{mL}^{-1}\right)$ incubated with $\mathrm{Au}$ NPs $\left(0.5 \mathrm{mg} \mathrm{mL}^{-1}\right)$ (white) and luciferase $\left(1 \mathrm{mg} \mathrm{mL}^{-1}\right)$ incubated with PEG-Au NPs $(0.5$ $\left.\mathrm{mg} \mathrm{mL}^{-1}\right)$ (black).

\section{Cell Viability study of luciferin loaded Au-MSN in Human Cervical Carcinoma}

(Hela) cells. Hela cells were seeded in 6 -well plates at a concentration of $1 \times 10^{5}$ cells $/ \mathrm{ml}$. Cells were incubated in D-10 medium (Dubelcco Modified Eagle's Medium with horse serum, L-alanyl-L-glutamine, gentamicin sulfate, and penicillinstreptomycin solution) for 24 hours at $37{ }^{\circ} \mathrm{C}$ in $5 \% \mathrm{CO}_{2}$. After that, D-10 medium was replaced by a suspension of luciferin loaded Au-MSN in D-10 medium $(20,50,100 \mu \mathrm{g} / \mathrm{ml})$. Hela cells were incubated with this suspension for another 24 hours. Finally, the cytotoxicity of the samples was evaluated by Guava ViaCount cytometry assay (Guava Technologies, Inc.; Hayward, CA). Hela cell viability was calculated as a percentage of viable cells treated with luciferin loaded Au-MSN compared to untreated cells (control), as shown in Figure S4. 


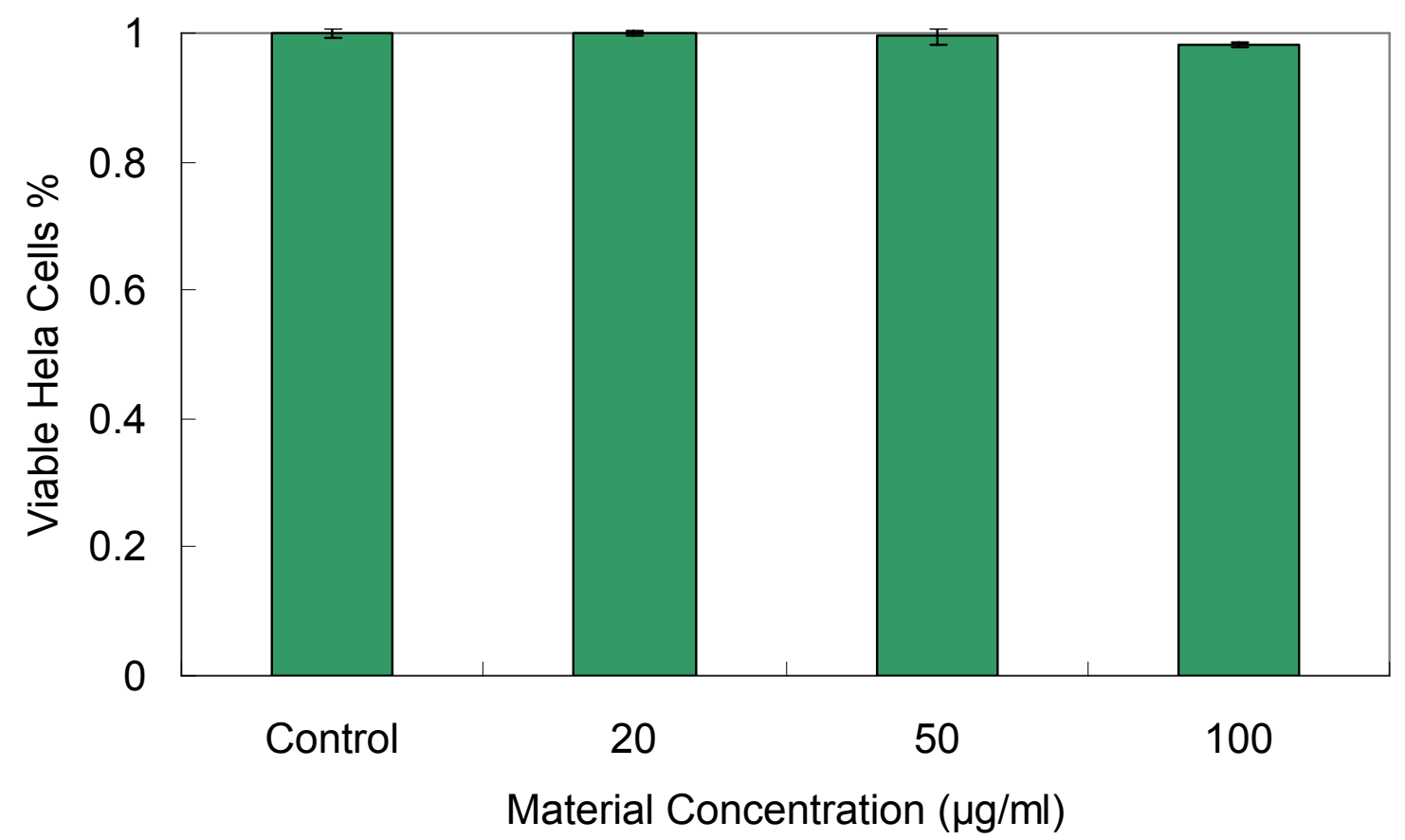

Figure S4: Cell viability study of Hela cells incubated with luciferase-luciferin Au-MSN at different concentrations.

Luciferin loaded Au-MSN endocytosis study with Hela cells. Linker-MSN was labeled by fluorescein isothiocyanate (FITC) based on our previous reports ${ }^{2}$. Hela cells at a concentration of $1 \times 10^{5}$ cells $/ \mathrm{ml}$ were incubated in 6 -well plates with D-10 medium for 24 hours at $37{ }^{\circ} \mathrm{C}$ in $5 \% \mathrm{CO}_{2}$. D-10 Medium was replaced by a suspension of luciferin loaded Au-MSN $(50 \mu \mathrm{g} / \mathrm{ml})$ in serum-free medium at $37{ }^{\circ} \mathrm{C}$ in $5 \% \mathrm{CO}_{2}$. At different time periods (10 $\mathrm{min}, 30 \mathrm{~min}, 60 \mathrm{~min}, 180 \mathrm{~min}, 360 \mathrm{~min}, 540 \mathrm{~min}$ ), the cells were washed with PBS, trypsinized and centrifuged. The pellets were incubated with $830 \mathrm{mM}$ tryphan blue before flow cytometry analysis (BD FACSCanto instrument). An aliquot of sample was mounted between plastic coverslips and imaged in a Leica SP5 X confocal system. 


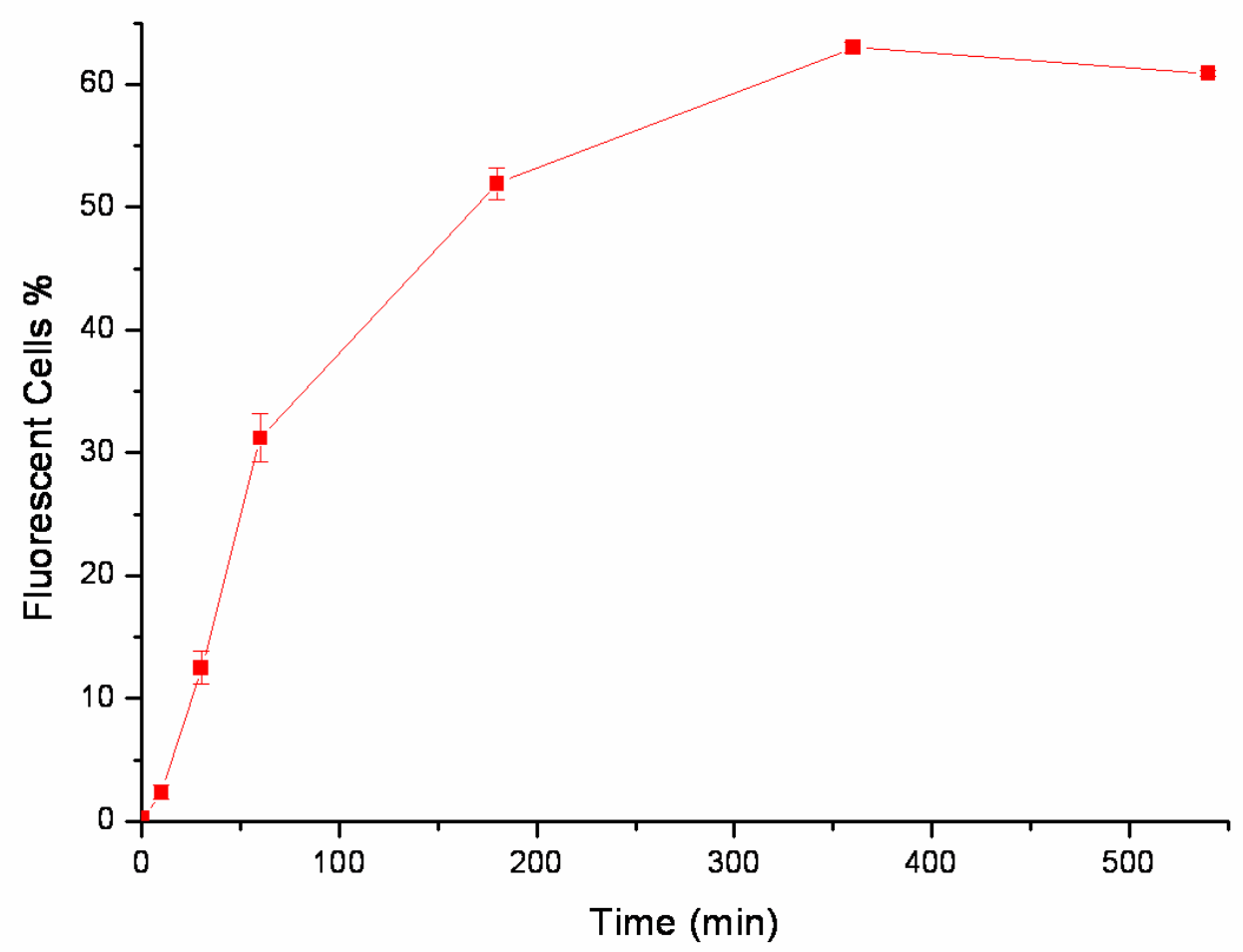

Figure S5: Endocytosis kinetics measurement of Hela cells incubated with luciferase-luciferin Au-MSN (50 $\mu \mathrm{g} / \mathrm{ml})$

Confocal fluorescence microscopy. Coverslips $\left(22 \mathrm{~mm}^{2}\right)$ were cleaned with 1.0 $\mathrm{M} \mathrm{HCl}$, nanopure water $(3 \times), 50 \%$ ethanol, $70 \%$ ethanol, and $100 \%$ ethanol, and dried overnight at $60{ }^{\circ} \mathrm{C}$. Cleaned coverslips were placed on the bottom of the wells of 6-well plates. Hela cells at a concentration of $1 \times 10^{5}$ cells $/ \mathrm{ml}$ were incubated in coverslips contained 6-well plates with D-10 medium at $37{ }^{\circ} \mathrm{C}$ in $5 \% \mathrm{CO}_{2}$. After 24 hours, medium was replaced by a suspension of luciferin loaded Au-MSN $(50 \mu \mathrm{g} / \mathrm{ml})$ in serum-free medium. Hela cells were incubated for 3 hours. Following that, medium was removed, and the cells were washed with PBS $(2 \times)$ and incubated for 30 min with a PBS solution of 3.7\% formaldehyde and 57.0 mM 4,6-Diamidino-2-phenylindole dihydrochloride (DAPI). 
Coverslips were then taken out from the PBS solution and fixed to glass slides. Confocal fluorescence images were obtained by a Leica SP5 X confocal system.

Transmission Electron Microscopy (TEM) of Hela cell incubated with

luciferase-luciferin Au-MSN. Hela cells were prepared as above and incubated with material suspension (50 $\mu \mathrm{g} / \mathrm{ml}$ in D-10 medium) for 3 hours. The cells were then fixed by adding a $1 \%$ glutaraldehyde solution dropwise over $5 \mathrm{~min}$ and further incubated at 37 ${ }^{\circ} \mathrm{C}$ for $1.5 \mathrm{~h}$. Samples were post-fixed with $1 \%$ osmium tetroxide in PBS for $1.5 \mathrm{~h}$. Cells were dehydrated in increasing concentrations of ethanol $(50 \%, 60 \% 70 \%, 80 \%$, $90 \%$, and $100 \%$ ) for 15 min each and stained with $2 \%$ uranyl acetate in $70 \%$ ethanol at room temperature overnight. The cells were washed three times with acetone and embedded in Epon. Embedded samples were sectioned in $60 \mathrm{~nm}$ thick slices on a sliding ultramicrotome. Thin sections supported on copper grids were examined with a Tecnai G2 F20 transmission electron microscope operated at $200 \mathrm{kV}$.

\section{References}

1. Brust, M.; Walker, M.; Bethell, D.; Schiffrin, D. J.; Whyman, R. J. Chem. Soc., Chem. Commun. 1994, 7, 801-802.

2. Zhao, Y.; Sun, X.; Zhang, G.; Slowing, I. I.; Trewyn, B. G.; Lin, V. S. Y. ACS Nano 2011, 5, 1366-1375. 


\title{
CHAPTER 3. FUNCTIONALIZED MESOPOROUS SILICA NANOPARTICLE BASED HETEROGENEOUS CATALYST FOR C-H BOND ACTIVATION REACTION
}

\author{
Xiaoxing Sun, Hung-ting Chen, Brian G. Trewyn* and Victor S.-Y. Lin ${ }^{\dagger}$ \\ Department of Chemistry, U.S. Department of Energy and Ames Laboratory, Iowa State \\ University, Ames, Iowa 50011-3111, U.S.A.
}

\section{Introduction}

The production of ethylbenzene and related alkyl arenes is important in detergent and polymer industries, typically through traditional approaches such as Friedel-Crafts, Heck, Suzuki, Sonogashira reactions. ${ }^{1-3}$ However, significant drawbacks are present. For example, high energy input requirement and large waste generation. To overcome these drawbacks, an alternative method was developed using Pt (II) complexs for the C-H bonds activation ${ }^{4-6}$. The reaction was based on a Pt-mediated $\mathrm{C}-\mathrm{H}$ activation pathway with relatively high turnover numbers rather than a traditional Friedel-Crafts pathway.

Silica was widely used as a heterogeneous catalyst support because it is inert to active metals. And mesoporous silica nanoparticle has demonstrated its excellence due to the follwing two reasons: large surface area, which provides a high loading of active sites, and the tunable pore diameter and relatively large pore volume, which facilitates mass transfer $^{7-10}$. Here we developed a synthetic method of mesoporous silica nanoparticles 
with diameter of $10 \mathrm{~nm}$ (LP10-MSN). The large pore diameter and spacious pore volume offer an excellent nano-space to accommodate the bulky Pt complexs, whose size is around 1-2 nm, as determined by X-ray crystallographic structure.

\section{Experimental Method}

Synthesis of Organosilanes: Here we investigated on the synthesis of an organo silane, 2,2'-Bipyridine-amide-triethoxylsilane (Bpy-amide-TES). The structures are shown in Figure 1. 2,2'-Bipyridine-amide-triethoxylsilane was synthesized according to a modified method reported by $\mathrm{Chen}^{11}$ as depicted in Figure 2. The di-acid was suspended in thionyl chloride and refluxed under Ar until complete dissolution of di-acid (about 20 h). The excess of $\mathrm{SOCl}_{2}$ was removed by distillation to yield crude acid chloride. The resulting acid chloride was dissolved in $\mathrm{CH}_{2} \mathrm{Cl}_{2}$ and was added dropwisely into a $\mathrm{CH} 2 \mathrm{Cl} 2$ solution of 3-aminopropyltrimethoxysilane and NEt3. The solution became pink color and smoke was generated due to neutralization. After addition, the mixture was stirred at room temperature for one hour and the refluxed for another hour. The solution was washed by water twice and brine once. The organic layer was dried with MgSO4 and concentrated under the vacuum to yield light pink white powder. Bpy-amide-TES was immobilized onto silica support by both post-grafting method and co-condensation method. 


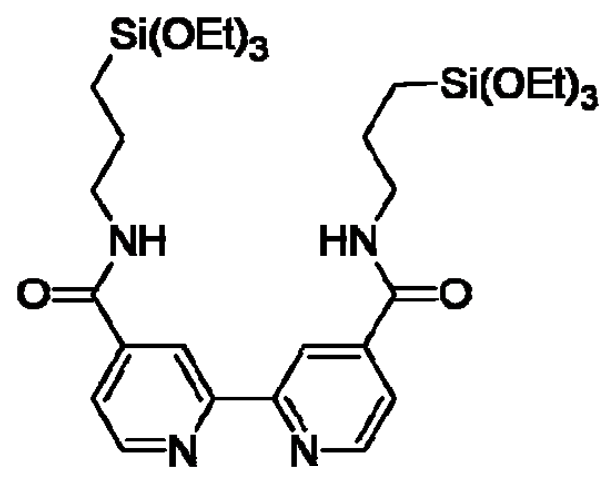

Figure 1. Structure of 2,2'-Bipyridine-amide-triethoxylsilane (Bpy-amide-TES)

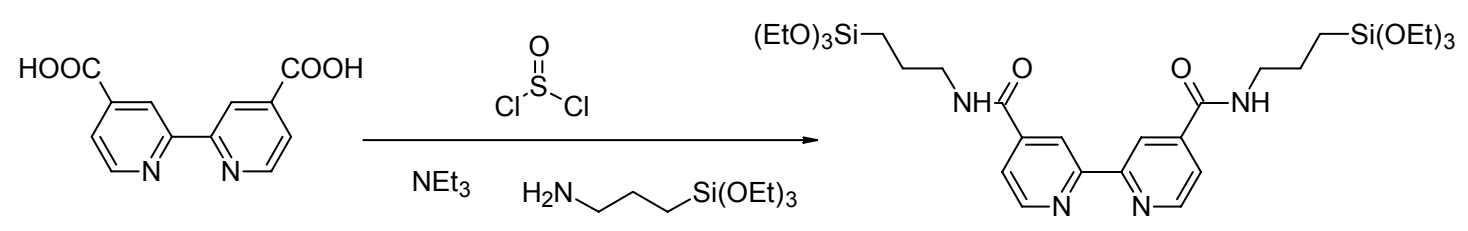

Figure 2. Reaction scheme of Bpy-amide-TES synthesis

Post-grafting Method: In the first strategy, unfunctionalized LP10-MSN was synthesized based on a previous method ${ }^{12}$. In brief, the tetramethoxysilane (TMOS) was stirred in the $1.6 \mathrm{M} \mathrm{HCl}$ solution at $56^{\circ} \mathrm{C}$ using PEO-PPO-PEO triblock copolymer (P104) as surfactant for 24 hours. The mixture was transferred into a high-pressure reactor for aging at $150{ }^{\circ} \mathrm{C}$ for another 24 hours. The resulting as-made LP10-MSN was filtered, washed with copious amount of water and methanol, and dried under vacuum. The P104 was removed by calcination at $600{ }^{\circ} \mathrm{C}$ for $6 \mathrm{~h}$ to yield non-functionalized LP10-MSN materials. Varieties of organic groups for anchoring organometallics can be immobilized onto LP10-MSN by a post-grafting method. Typically, the surfactant-free LP10-MSN was dried at $110{ }^{\circ} \mathrm{C}$ under vacuum for $4 \mathrm{~h}$ to remove adsorbed moisture. After cooling down to room temperature, Bpy-amide-TES in the toluene solution was charged to the LP10-MSN. 
The mixture was refluxed for $20 \mathrm{~h}$, followed by filtration, washing, and dried under vacuum to obtain functionalized LP10-MSNs. This post-grafting method significantly maintained the well ordered 2D hexagonal mesopore structures.

Co-condensation Method: In the second approach, a co-condensation method was applied, which results in a homogeneous distribution of organometallics. Triblock copolymer $\mathrm{P} 104$ was stirred in the $1.6 \mathrm{M} \mathrm{HCl}$ solution at $56{ }^{\circ} \mathrm{C}$ for 30 minutes to allow full dissolution. TMOS was added and stirred with the above solution at $56{ }^{\circ} \mathrm{C}$ for 30 minutes and white precipitate was generated. Bpy-amide-TES in hot ethanol solution was stirred with the mixture for 24 hours. Similar to the synthesis of unfunctionalized LP10-MSN, the mixture was transferred into a high-pressure reactor for aging at $150{ }^{\circ} \mathrm{C}$ for another 24 hours. The resulting as-made bipyridinyl-functionalized LP10-MSN was filtered, washed with copious amount of water and methanol, and dried under vacuum. The P104 was removed by refluxing in ethanol for 24 hours to yield bipyridinyl-functionalized LP10-MSN materials.

\section{Results and Discussion}

To investigate the material structures, powder X-ray diffraction (XRD) tests and $\mathrm{N}_{2}$ adsorption/desorption analysis were performed. XRD patterns of the MSN materials were collected in a Rigaku ultima IV X-ray diffractometer using $\mathrm{Cu} \mathrm{K \alpha}$ irradiation (Figure 3). Both bipyridinyl group functionalized LP10-MSN materials (post-grafting method and co-condensation method) exhibited the typical diffraction patterns of SBA-15 type mesoporous silica with highly ordered MSN parallel structures and hexagonal symmetry. 
$\mathrm{N}_{2}$ adsorption/desorption analysis was measured by nitrogen sorption isotherms in a Micromeritics Tristar 3000 sorptometer (Figure 4). The surface areas were calculated by the Brunauer-Emmett-Teller (BET) method, and the pore size distribution was calculated by the Barrett-Joyner-Halenda (BJH) method, as detailed in Table 1.

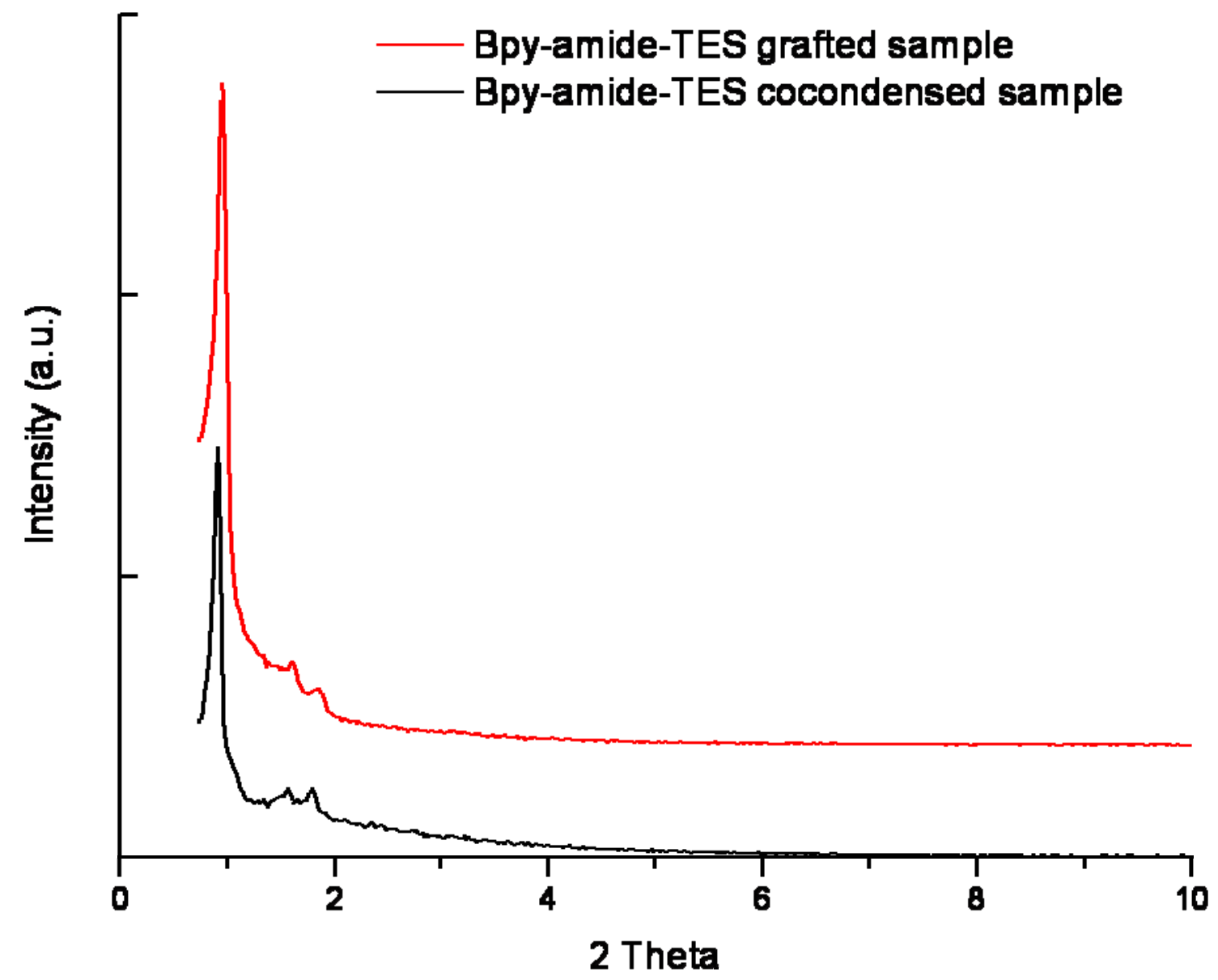

Figure 3. Low angle X-ray diffraction pattern of Bpy-admie-TES grafted LP10-MSN (red) and Bpy-amide-TES cocondensed LP10-MSN (black). 
(a)

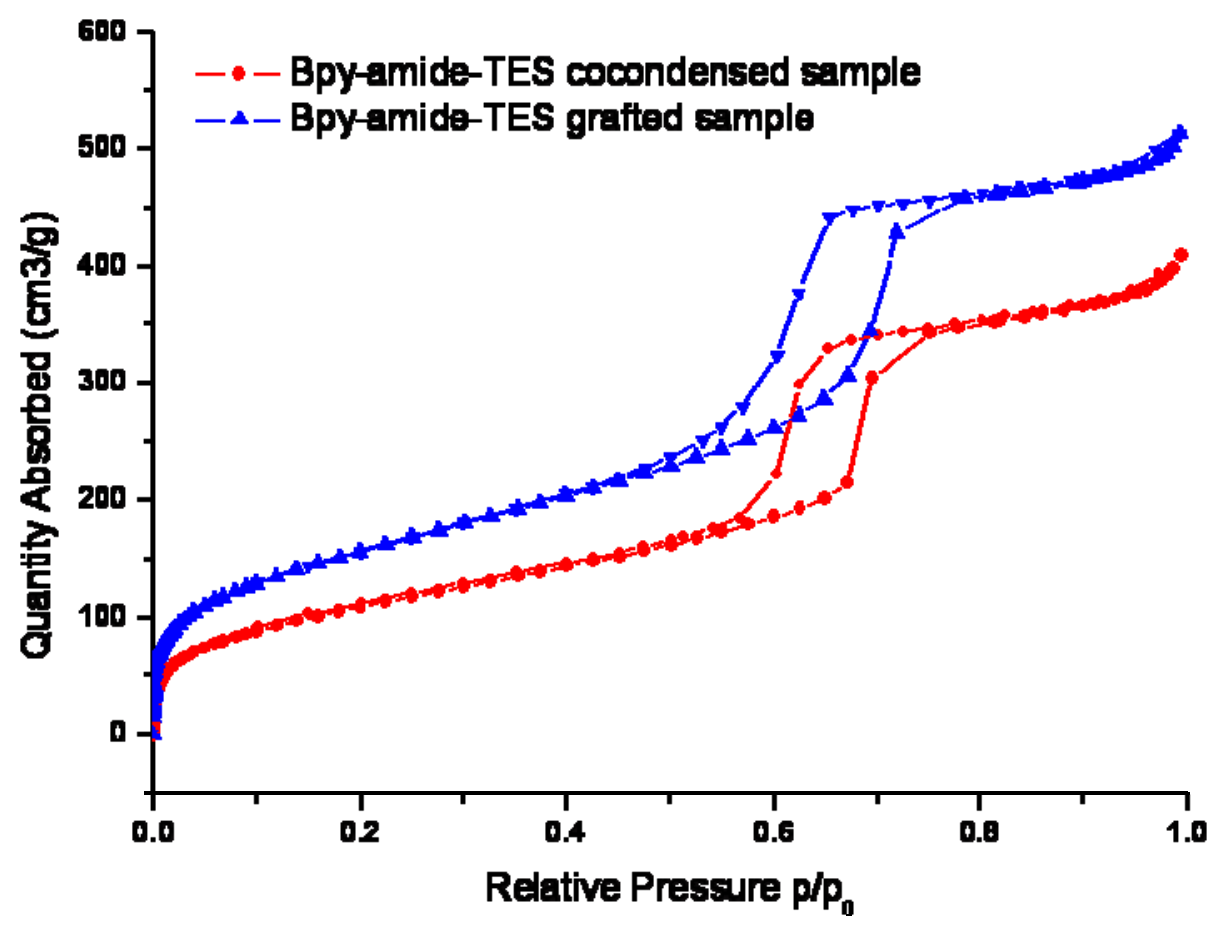

(b)

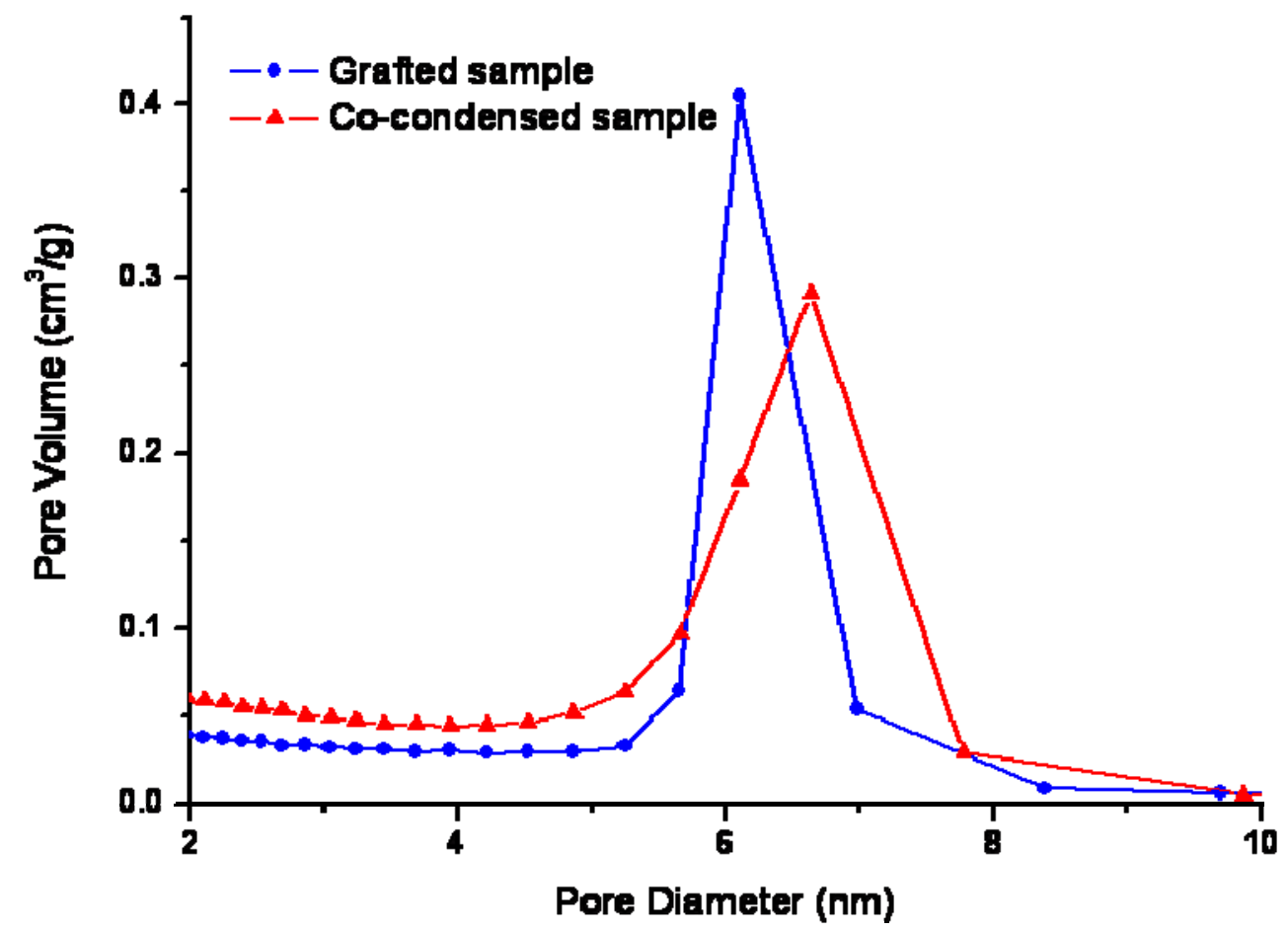

Figure 4. (a) $\mathrm{N}_{2}$ adsorption/desorption isotherms of Bpy-admie-TES grafted LP10-MSN (blue triangle) and Bpy-amide-TES cocondensed LP10-MSN (red dot). (b) Pore size distribution of Bpy-admie-TES grafted LP10-MSN (blue dot) and Bpy-amide-TES cocondensed LP10-MSN (red triangle). 
Table S1: BET and BJH parameters

\begin{tabular}{|c|c|c|c|}
\hline Material & $\begin{array}{c}\text { BET surface area } \\
\mathrm{S}_{\mathrm{BET}}\left(\mathrm{m}^{2} / \mathrm{g}\right)\end{array}$ & $\begin{array}{c}\text { BET Pore Volume } \\
V_{\mathrm{P}}\left(\mathrm{cm}^{3} / \mathrm{g}\right)\end{array}$ & $\begin{array}{c}\text { BJH Pore } \\
\text { diameter } \\
\mathrm{W}_{\text {BJH }}(\AA)\end{array}$ \\
\hline $\begin{array}{c}\text { Bpy-admie-TES grafted } \\
\text { LP10-MSN }\end{array}$ & 578 & 0.79 & 5.4 \\
\hline $\begin{array}{c}\text { Bpy-amide-TES } \\
\text { cocondensed } \\
\text { LP10-MSN }\end{array}$ & 407 & 0.63 & 5.8 \\
\hline
\end{tabular}

To study the morphology of the material, particle was studied with a JEOL 840A scanning electron microscope with a $10 \mathrm{kV}$ acceleration voltage, depicted in Figure 5. Morphology of Bpy-amide-TES grafted LP10-MSN, showing a well-ordered hexagonal disk-like shape, is consistent with the XRD result. However, morphology of Bpy-amide-TES cocondensed LP10-MSN revealed a football-like shape with each particle head-to-tail connected. 

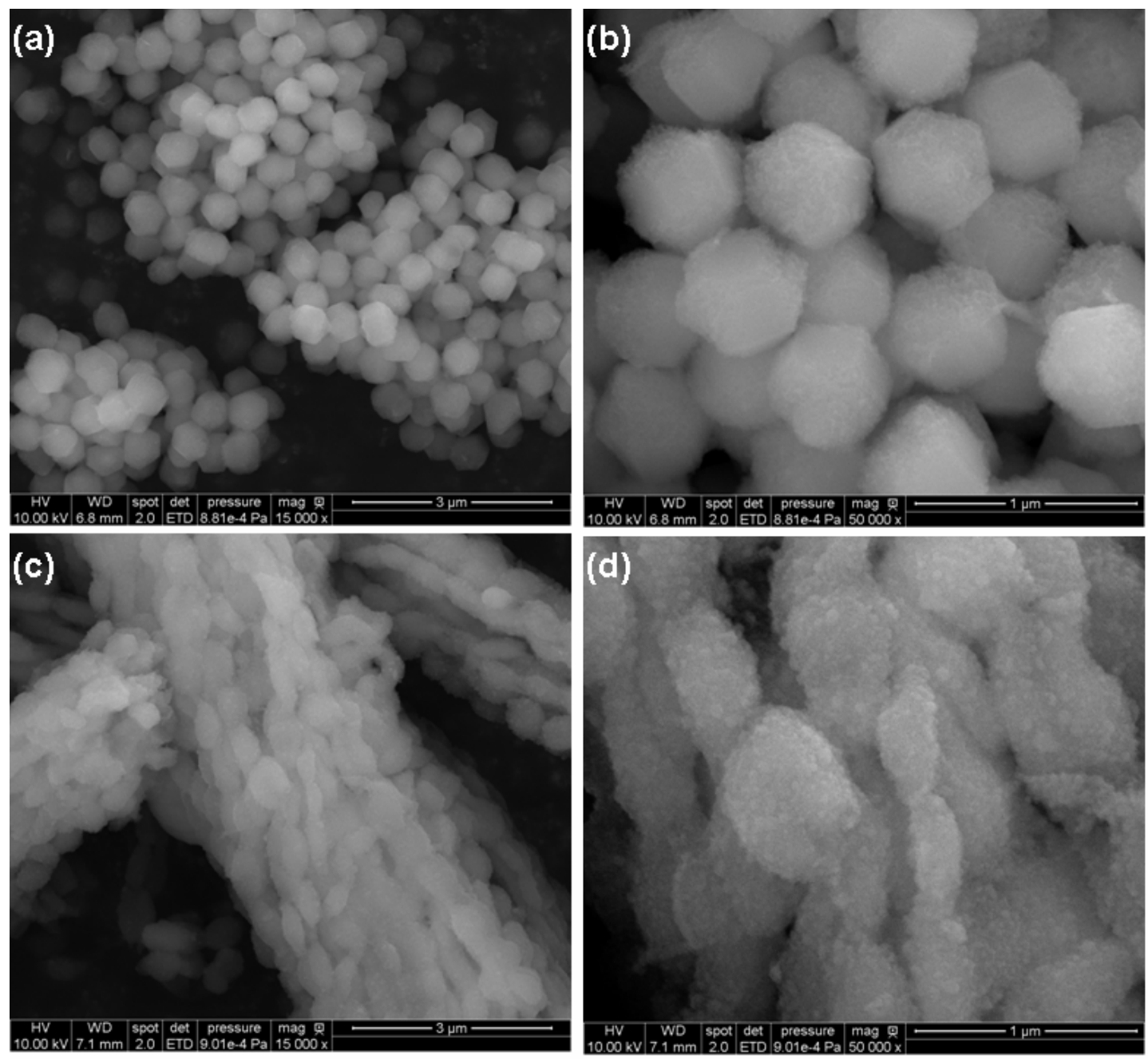

Figure 5. Scan electron microscopy images of Bpy-admie-TES grafted LP10-MSN (a, b) and Bpy-amide-TES cocondensed LP10-MSN (c, d). Images increase in magnification from left to right.

The distribution and loading amount of bipyridinyl groups was measured by ${ }^{29} \mathrm{Si}$ direct polarization (DP) solid-state NMR spectroscopy, shown in Figure 6. Bpy-amide-TES co-condensed LP10-MSN had a loading of $0.46 \mathrm{mmol} / \mathrm{g}$ and showed normal loading with $\mathrm{T}^{2}$ and $\mathrm{T}^{3}$ sites. Bpy-amide-TES grafted sample had a loading of $0.44 \mathrm{mmol} / \mathrm{g}$. However, it exhibited different behavior with a large amount of $\mathrm{T}^{1}$ sites, as 
well as the presence of $\mathrm{T}^{0}, \mathrm{~T}^{2}$ and $\mathrm{T}^{3}$ peaks. The small amount of $\mathrm{T}^{0}$ sites imply that a few of the groups have only one linker attached to the silica surface, while the other linker is "floating". The high presence of the $\mathrm{T}^{1}$ sites could be due to the bulky nature of the group, allowing the group to site farther from the surface.
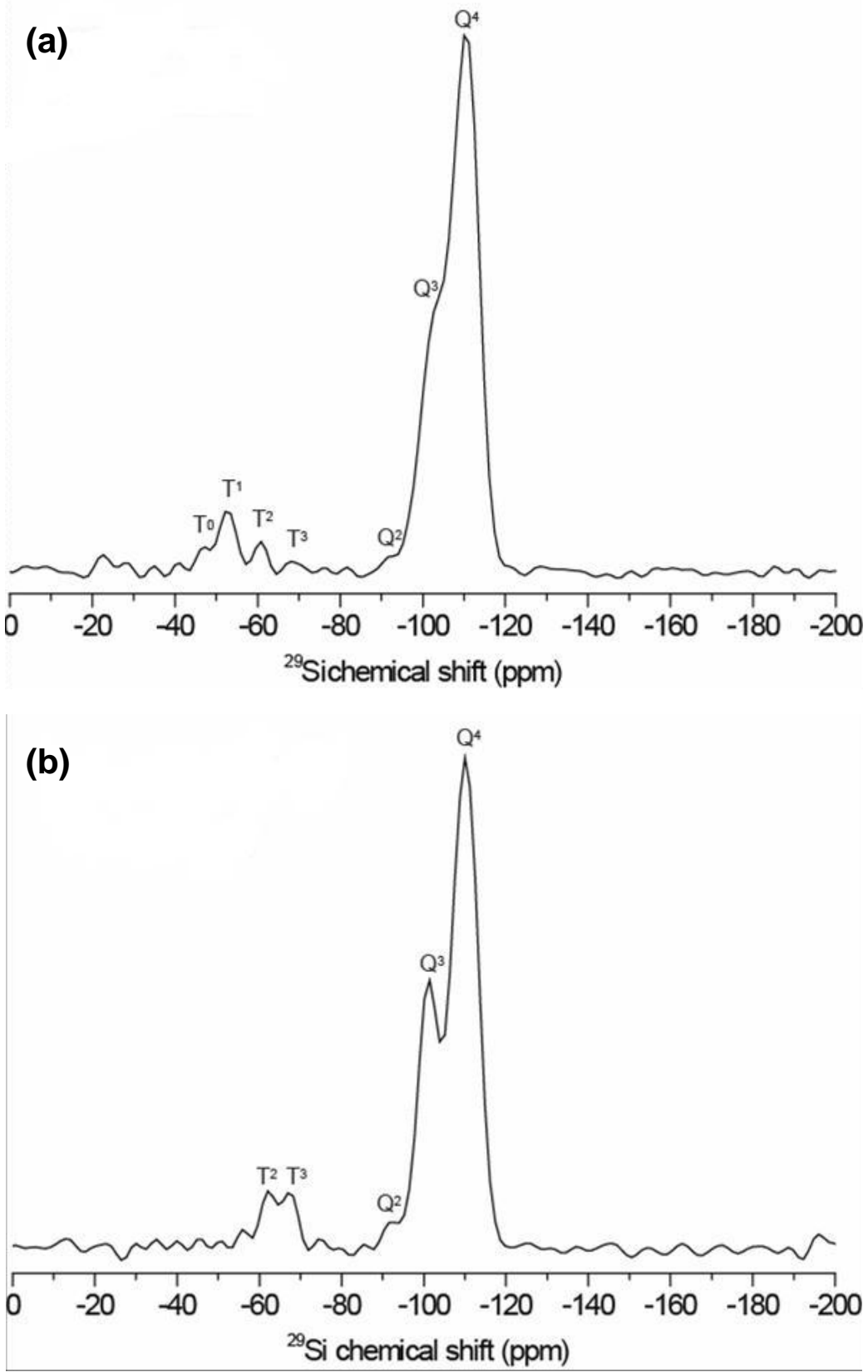

Figure 6. ${ }^{29} \mathrm{Si}$ solid state NMR spectra of (a) Bpy-admie-TES grafted LP10-MSN and (b) Bpy-amide-TES cocondensed LP10-MSN. 


\section{Conclusion}

We have successfully immobilized Bpy-amide-TES onto LP10-MSN by both post-grafting method and co-condensation method. This material we have synthesized would obtain further interest in complexation with platinum for the $\mathrm{C}-\mathrm{H}$ bond activation reaction, for example, ethylene/benzene reaction, with relatively high turnover numbers.

\section{Acknowledgement}

This material is based upon work supported as part of the Center for Catalytic Hydrocarbon Functionalization, an Energy Frontier Research Center funded by the U.S. Department of Energy, Office of Science, Office of Basic Energy Sciences under Award Number DE-SC0001298

\section{References}

1. Stille, J. K. Angew. Chem., Int. Ed. Engl. 1986, 25, 508-524.

2. Miyaura, N.; Suzuki, A. Chem. Rev. 1995, 95, 2457-2483.

3. Beletskaya, I. P.; Cheprakov, A. V. Chem. Rev. 2000, 100, 3009-3066.

4. McKeown, B. A.; Foley, N. A.; Lee, J. P.; Gunnoe, T. B. Organometallics 2008, 27, 4031-4033.

5. Shilov, A. E.; Shul'pin, G. B. Chem. Rev. 1997, 97, 2879-2932.

6. Lersch, M.; Tilset, M. Chem. Rev. 2005, 105, 2471-2526.

7. Martinez, A.; Prieto, G. Top. Catal. 2009, 52, 75-90. 
8. Beck, J. S.; Vartuli, J. C.; Roth, W. J.; Sheppard, E. W.; et al. J. Am. Chem. Soc. 1992, $114,10834-10843$.

9. Kresge, C. T.; Leonowicz, M. E.; Roth, W. J.; Vartuli, J. C.; Beck, J. S.

Nature 1992, 359, 710-712.

10. Song, H.; Rioux, R. M.; Hoefelmeyer, J. D.; Komor, R.; Niesz, K.; Grass, M.;

Yang, P.; Somorjai, G. A. J. Am. Chem. Soc. 2006, 128, 3027-3037.

11. Chen, H.; Kuranari, S.; Matsuoka, M.; Zhang, J.; Anpo, M. Catal. Lett. 2008, 126, $218-223$

12. Zhao, Y.; Sun, X.; Zhang, G.; Slowing, I. I.; Trewyn, B. G.; Lin, V. S. Y. ACS Nano 2011, 5, 1366-1375. 


\section{CHAPTER 4. GENERAL CONCLUSIONS}

Applications of mesoporous silica nanoparticles (MSN) have been extensively developed since the discovery of mesoporous materials. Unique features of MSN, such as large surface area, tunable pore diameter, controlled particle size and morphology, excellent biocompatibility, offer great advantage. Contributions in both biomedical field and catalytical field have been made in Dr. Lin's and Dr. Trewyn's group, using MSN to serve either as a multi-biomolecules intracellular delivery vehicle with preserved bioactivity or as support for noble metal catalyst complexation.

As a biomolecule intracellular delivery vehicle, MSN was functionalized with poly-ethylene glycol to prevent nonspecific interaction between silica surface and biomolecules and to preserve their bioactivity. The presence of both mesopore channels and outer particle surface provides the possibility to delivery several biomolecules simultaneously. So that biomolecules are guaranteed to be delivered to the same spot. Moreover, the pore openings were capped with gold nanoparticles so that the release of biomolecules that was loaded inside mesopores can be trigger controlled, either by internal stimuli (intracellular environment) or by external stimuli (dithiothreitol) by the intracellular environment itself, to manipulate the delivery with accurate control of site and timing. We also demonstrated an in vitro luciferase catalyzed light generating reaction of luciferin into oxyluciferin with the help of intracellular ATP. This system makes the co-delivery of an enzyme and its substrate possible so that we may artificially control intracellular reactions or manipulate cells to generate desired molecules in the future. 
As a support for noble metal catalyst, LP10-MSN was utilized for its enhanced mass-transfer efficiency. Bipyridinyl silane was successfully synthesized and immobilized onto LP10-MSN by two conventional method, post-grafting and co-condensation. Hexagonal mesopore structure was retained after bipyridinyl functionalization. This material would obtain further interest in complexation with platinum for the $\mathrm{C}-\mathrm{H}$ bond activation reaction, for example, ethylene/benzene reaction, with relatively high turnover numbers

The research presented in this dissertation opens the door for the design of series of novel biomolecules co-delivery systems as well as the development of the existing noble metal catalyst. However, applications of MSN are not limited to what has been discussed here. Further work, such as in vivo application, still needs to be investigated. 